\title{
ЭЛЕМЕНТЫ-ПРИМЕСИ В СУЛЬФИДАХ И ЗОЛОТЕ МЕСТОРОЖДЕНИЯ ОЛИМПИАДА (ЕНИСЕЙСКИЙ КРЯЖ): ИСТОЧНИКИ ВЕЩЕСТВА И ПАРАМЕТРЫ ФЛЮИДА
}

Сильянов С. А., Сазонов А. М., Тишин П. А., Лобастов Б. М., Некрасова Н. А., Звягина Е. А., Рябуха М. А.

\begin{abstract}
Аннотация
В статье рассмотрены особенности распределения редких, рассеянных элементов и благородных металлов в сульфидах и самородном золоте месторождения Олимпиада. Анализ полученных данных позволил сделать ряд предположений об источнике рудного вещества и параметрах рудообразующего флюида. Нами предполагается, что месторождение сформировано флюидом средних-высоких температур, переменной солености и кислотности-щелочности, при доминировании хлоридных комплексов. Редокс-потенциал изменялся в ходе рудообразования, однако рудная минерализация сформирована при доминировании восстановительных обстановок. Установлено, что ранняя Au-As минерализация сформирована при превалирующем участии корового вещества, при этом не исключается привнос части вещества из другого, возможно, глубинного источника. Au-Sb ассоциация разительно отличается по распределению REE, а также благородных металлов (в первую очередь PGE), что интерпретируется нами как указание на отличный источник вещества (с большей долей глубинной составляющей) при формировании таких парагенезисов. Данные о Au/Ag отношении в сульфидах, золоте и рудах месторождения позволяют предположить наличие минеральных форм сульфидов Au и Ag.
\end{abstract}

\section{Ключевые слова:}

Енисейский кряж, месторождение Олимпиада, золото, сульфиды, REE, рассеянные элементы, благородные металлы, источники вещества 


\title{
ЭЛЕМЕНТЫ-ПРИМЕСИ В СУЛЬФИДАХ И ЗОЛОТЕ МЕСТОРОЖДЕНИЯ ОЛИМПИАДА (ЕНИСЕЙСКИЙ КРЯЖ): ИСТОЧНИКИ ВЕЩЕСТВА И ПАРАМЕТРЫ ФЛЮИДА
}

\author{
С.А. Сильянов ${ }^{1}$, А.М. Сазонов ${ }^{1}$, П.А. Тишин ${ }^{2}$, Б.М. Лобастов ${ }^{1}$, Н.А. Некрасова ${ }^{1}$, \\ Е.А. Звягина ${ }^{1}$, М.А. Рябуха ${ }^{3}$ \\ ${ }^{1}$ Сибирский федеральный университет, Россия, 660041, Красноярск, пр. Свободный, 79 \\ ${ }^{2}$ Томский государственный университет, Россия, 634050, Томск, пр. Ленина, 36 \\ ${ }^{3}$ Институт геологии и минералогии им. В.С. Соболева СО РАН, Россия, 630090, \\ Новосибирск, пр. Академика Коптюга, 3
}

\begin{abstract}
Аннотация
В статье рассмотрены особенности распределения редких, рассеянных элементов и благородных металлов в сульфидах и самородном золоте месторождения Олимпиада. Анализ полученных данных позволил сделать ряд предположений об источнике рудного вещества и параметрах рудообразующего флюида. Нами предполагается, что месторождение сформировано флюидом средних-высоких температур, переменной солености и кислотности-щелочности, при доминировании хлоридных комплексов. Редокс-потенциал изменялся в ходе рудообразования, однако рудная минерализация сформирована при доминировании восстановительных обстановок. Предполагается, что ранняя Au-As минерализация могла быть сформирована при превалирующем участии корового вещества, при этом не исключается привнос части вещества из другого, возможно, глубинного источника. Au-Sb ассоциация разительно отличается по распределению REE, а также благородных металлов (в первую очередь PGE), что может интерпретироваться как указание на отличный источник вещества (с большей долей глубинной составляющей) при формировании таких парагенезисов. Данные о $\mathrm{Au} / \mathrm{Ag}$ отношении в сульфидах, золоте и рудах месторождения позволяют предположить наличие минеральных форм сульфидов Au и Ag.
\end{abstract}

Ключевые слова: Енисейский кряж, месторождение Олимпиада, золото, сульфиды, REE, рассеянные элементы, благородные металлы, источники вещества, генезис, ICP-MS

\section{TRACE ELEMENTS IN SULFIDES AND GOLD OF THE OLIMPIADA DEPOSIT (YENISEI RIDGE): SUBSTANCE SOURCES AND FLUID PARAMETERS}

\author{
S.A. Silyanov ${ }^{1}$, A.M. Sazonov ${ }^{1}$, P.A. Tishin ${ }^{2}$, B.M. Lobastov ${ }^{1}$, N.A. Nekrasova ${ }^{1}$, \\ E.A. Zvyagina ${ }^{1}$, M. A. Ryabukha ${ }^{3}$
}

${ }^{1}$ Siberian Federal University, pr. Svobodny 79, Krasnoyarsk, Russia, 660041

${ }^{2}$ Tomsk State University, pr. Lenina 36, Tomsk, Russia, 634050

${ }^{3}$ V.S. Sobolev Institute of Geology and Mineralogy of the Siberian Branch of the Russian Academy of Science, pr. Akademika Koptyuga, 3, Novosibirsk, Russia, 630090 


\begin{abstract}
The paper describes the features of distribution of rare, dispersed elements and precious metals in sulfides and native gold of the Olimpiada deposit. The analysis of the data received allows making a number of assumptions on the source of the ore substance and parameters of the ore forming fluid. We think that the deposit was formed by the medium- and high-temperature fluid with variable salinity and acidity-alkalinity, with chloride complexes dominating. The REDOX potential changed in the course of ore formation, but the ore mineralization was formed with the reduction conditions prevailing. It has been found out that the early Au-As mineralization was formed at the predominant participation of the crust substance, while the supply of a part of substance from another, probably, deep source is possible. The Au-Sb association differs much in the REE as well as precious metals (primarily PGE) distribution, which is interpreted by us as an indication of a different source of substance (with a higher share of a deep component) during the formation of such parageneses. The data on the Au/Ag ratio in sulfides, gold and ore of the deposit allows assuming the presence of mineral forms of Au and Ag sulfides.
\end{abstract}

Key words: Yenisei Ridge, Olimpiada deposit, gold, sulfides, REE, dispersed elements, precious metals, ore substance sources, genesis, ICP-MS

Corresponding author: E-mail: Silyanov-s@mail.ru

\title{
ВВЕДЕНИЕ
}

Золоторудное месторождение Олимпиада расположено в пределах Восточного золотоносного пояса Енисейского кряжа (Красноярский край) и является одним из крупнейших по запасам золота в России и Мире. На начало 2018 г. запасы с учетом добычи составили более 1560 т.

Месторождение характеризуется уникальным вещественным составом руд и сложностью геологического строения, что вместе с данными абсолютной геохронологии говорит о полистадийной и полихронной истории его формирования. История изучения месторождения насчитывает около 50 лет (начиная с 1968-1974 гг.), за это время в разной степени было освещено множество аспектов геологии и генезиса руд, однако ряд вопросов остается дискуссионным.

Одним из них является источник рудного вещества. В настоящее время предполагается три основные гипотезы. Первая основана на предположении о первичноосадочной природе золота, не только месторождения, но и региона в целом, с последующей его мобилизацией и переотложением в процессе диагенеза, метагенеза и метаморфизма [Петров, 1974, 1976]. Вторая базируется на магматогенно-гидротермальном рудообразовании, связанном с кислым или основным магматизмом региона [Ли, 2003]. В рамках третьей предполагается обогащение металлом первичных осадков, а перераспределение полезных компонентов происходит за счет флюидов различного генезиса, при этом допускается, что подобные флюиды также могут являться носителем металла [Сазонов, 1998; Сазонов и др.,2010; Кряжев, 2017; Сильянов и др., 2018]. Аргументация этих гипотез в настоящее время базируется на изотопных исследованиях (S, $\mathrm{Os,} \mathrm{He,} \mathrm{Pb}$, и др.) рудных минералов месторождения.

В дополнение к изотопно-геохимическим данным, генетическую информацию об источнике рудообразующего флюида и рудного вещества, можно получить при анализе распределения элементов-примесей (в первую очередь REE, а также рассеянных 
элементов и благородных металлов) в сульфидных минералах и золоте [Горячев и др., 2008; Некрасова и др., 2010; Волков и др., 2016; Знаменский, 2017; Сильянов и др., 2018; Guangzhou et. al., 2009; Barnes, Liu, 2012; Kun et al., 2014; Xiaohu, et al., 2014; Le Vaillant, et al., 2018]. В основу такого анализа положено предположение о том, что состав микроэлементов и REE рудных минералов (сульфидов и золота) наследует микроэлементный состав и REE-характеристики рудообразующего флюида [Kun et al., 2014]. Стоит отметить, что при интерпретации подобных данных существуют определенные проблемы. Основной из которых является форма нахождения REE и других элементов-примесей в рудных минералах месторождений золота. Очевидна возможность изоморфного вхождения в решетку сульфидов и золота таких элементов как $\mathrm{Co}, \mathrm{Ni}, \mathrm{Cu}, \mathrm{Pb}$, $\mathrm{Bi}$ и др. Формы нахождения благородных металлов (в первую очередь $\mathrm{Au}$ и $\mathrm{Ag}$, а также PGE) в сульфидных минералах активно обсуждаются - предполагается возможность изоморфизма металлов в структуру сульфидов [Genkin, et al., 1998; Cabri, et al., 2000]; сорбция частиц и атомов металлов на поверхности растущих кристаллов, а также их аккумуляция в структурных дефектах [Таусон и др., 2011; Кравцова и др., 2015]; подобные элементы также могут присутствовать в металлической форме в виде включений нано и микро размера. Относительно REE существуют предположения о том, что они накапливаются во флюидных включениях, также возможно их концентрирование в дефектах кристаллической структуры, изоморфное вхождение (для HREE) и сорбция на поверхности кристаллов (для LREE) [Римская-Корсакова, Дубинин, 2003]. Возможность вхождения лантанидов в решетку сульфидов подтверждается близостью ионных радиусов REE и главных катионов сульфидов [Morgan, Wandless, 1980]. Не исключена возможность концентрирования REE в минеральных микровключениях, однако, по данным M. Гуанчжоу с соавторами, состав REE в силикатной фазе микровключений является частью общего баланса лантаноидов флюида, из которого кристаллизовался сульфид, и поэтому валовый состав REE в минерале можно рассматривать как отражение состава рудообразующего флюида [Guangzhou, et al., 2009].

Второй важной проблемой при изучении распределения элементов-примесей (в первую очередь REE) в сульфидных минералах является тот факт, что в отличии от магматических и метаморфических систем, представление о фракционировании лантаноидов при гидротермальном процессе находится на стадии накопления фактического материала. Однако, несмотря на вышеперечисленные проблемы, анализ распределения малых элементов в рудных минералах, с последующими генетическими выводами, проведен для ряда месторождений золота [Афанасьева и др., 1997; Некрасова и др., 2010; Волков и др., 2016; Сильянов и др., 2018; Guangzhou et al., 2009; Kun et al., 2014 и др.].

Настоящая статья посвящена поиску подходов к решению генетических вопросов рудообразования на основании анализа распределения элементов-примесей в сульфидных минералах и золоте. Приведены результаты анализа распределения редких и рассеянных элементов, а также благородных металлов в главных рудных минералах (арсенопирит, пирит, пирротин и стибнит) и золоте месторождения Олимпиада (Енисейский кряж), на основании которых сделаны предположения о вероятностном источнике рудного вещества месторождения и физико-химических особенностях флюида. 
Олимпиадинское месторождение расположено в Заангарской части складчатого сооружения Енисейского кряжа байкальского возраста. Месторождение находится в центре Восточного золотоносного пояса кряжа в верхнем течении р. Енашимо, на водоразделе руч. Олимпиадинского, руч. Оленьего и р. Тырада, на площади листа O-46-III (Рис. 1, а). Рудное поле месторождения входит в состав Верхне-Енашиминского рудного узла Северо-Енисейского рудного района Енисейской золоторудной провинции.

Месторождение расположено в заливообразном стратифицированном обрамлении Чиримбинского гранито-сланцевого купола, осложняющего сводовую часть Панимбинского антиклинория северо-западного простирания (Рис. 1, b). Рудное поле месторождения определяется W-образной структурой, сформированной тремя сопряженными складками с субпараллельной северо-восточной ориентировкой крыльев и осевых поверхностей: Иннокентьевской и Чиримбинской синклиналями и Медвежинской антиклиналью (Рис. 1, b). Последняя является главной рудоконтролирующей структурой, занимая центральную и восточную часть рудного поля. В пределах рудного поля трассируются крупные зоны разломов: Верхне-Чиримбинская, Медвежинская (Главная), Широтная (Северная) и Оленья [Сазонов и др., 2019].

На территории рудного поля месторождения развиты отложения нижней, средней и верхней подсвит кординской свиты. Нижняя подсвита сложена кварцитовидными биотиткварцевыми роговикоподобными сланцами коричнево-серого цвета с пластами амфиболитовых сланцев зеленого цвета. Средняя подсвита является рудовмещающей и представлена серыми, зеленовато-серыми метаалевролитами с примесью карбонатного и углеродистого вещества, существенно карбонатными породами и черными углеродистыми сланцами. Верхняя подсвита сложена зеленовато-серыми слюдяными часто с полевым шпатом и гранатом кварцитовидными сланцами.

Метаморфическая толща по периметру окружена цепочкой гранитоидных массивов, на северо-западе - Тырадинский (однофазный куполовидный интрузивный выступ овальной формы, сложен гранитами и гранодиоритами, реже встречаются плагиограниты, грейзенезированные граниты) и Коноваловские интрузии гранитов, на юго-востоке - Верхне-Чиримбинский (крупный интрузив сложного и неоднородного строения, представлен порфировидными биотитовыми, амфибол-биотитовыми гранитами и гранодиоритами с маломощными зонами закалки), на северо-востоке - Енашиминская группа интрузий гранитов и лейкогранитов.

Рудные минералы формируют сеть субпараллельных «штриховатых» агрегатов, прожилков и гнездово-пятнистых скоплений мощностью от первых миллиметров до первых сантиметров и приурочены к гранат-двуслюдяным, карбонатным и кварцкарбонатным метасоматически-переработанным породам. Оруденение контролируется зонами дизъюнктивов, породы в пределах этих зон интенсивно рассланцованы, смяты в складки и микроскладки, субсогласно которым ориентированы вкрапления рудных минералов. Рудные тела оконтуриваются опробованием, по текущим кондициям.

На месторождении выделяется ряд устойчивых минеральных комплексов, несущих разномасштабное золотое оруденение. Наиболее ранний комплекс представлен вкрапленностью арсенопирита, пирита, пирротина и сульфидов полиметаллов. Этот тип руд характеризуется, преимущественно, тонким («невидимым») золотом. Поздний минеральный комплекс пространственно совмещен с ранним, соответствует золотомышьяк-сурьмяным парагенезисам и слагает Au-As-Sb руды с видимым золотом. Минерализация комплекса (поздние арсенопирит, пирит, пирротин, стибнит, бертьерит, 
гудмундит, блеклые руды, теллуриды висмута, ульманит, герсдорфит, видимое золото, ауростибит) сформирована со значительным отрывом во времени, после тектонической проработки ранее образованных ассоциаций. Участки наложения раннего и позднего комплексов характеризуются повышенными содержаниями благородного металла. Золото в коренных рудах преимущественно тонкое, пылевидное, его содержание достигает $n^{*} 10$ г/т. Видимое золото встречается исключительно редко и образует включения в кварце, арсенопирите, пирите, пирротине, бертьерит-стибните и, реже в карбонатах, гудмундите, халькопирите и др. Доля упорного, неизвлекаемого цианированием золота в рудах достигает 39-60\%, оно в основном связано в сульфидах, в первую очередь в арсенопирите, в котором концентрируется в количествах до 4.7 ppm [Генкин, 1998]. Проба золота, ассоциирующего с мышьяковистой минерализацией, высокая до 910-997\%о, основными примесями являются серебро, медь. Золото сурьмяных парагенезисов имеет пониженную пробу до 647-757\% с примесями сурьмы, меди, ртути, серебра и никеля.

По данным Н.А. Гибшер с соавторами кварц ранней продуктивной золотомышьяковой ассоциации образован при температурах 260-470 ${ }^{\circ} \mathrm{C}$ и давлениях 1.1-2.5 кбар, флюидом соленостью 9.5-20.0 мас.\% NaCl-экв., содержащим в основном хлориды $\mathrm{Mg}$ и $\mathrm{Na}$. Температуры образования заключительной золото-сурьмяной ассоциации значительно ниже - 240-300 C, при давлении 1.8-2.1 кбар, и солености 5.5-8.0 мас.\% NaCl-экв., в составе водной фазы отмечены хлориды натрия и магния [Гибшер и др., 2019b]. Флюид золото-мышьяковистых парагенезисов характеризуется обогащением углеводородами, и Sи $\mathrm{N}$-содержащими соединениями, а также $\mathrm{CO}_{2}$. Во флюиде, сформировавшем золотосурьмяные ассоциации, доминируют вода и углекислота, при подчиненном количестве углеводородов и S- и N-содержащих соединений [Гибшер и др., 2019b]. Авторами отмечается, что отложение разновозрастных минеральный ассоциаций происходило при изменяющихся окислительно-восстановительных условиях.

Н.А. Гибшер с соавторами был установлен возраст основных стадий минералообразования (Ar/Ar): ранний продуктивный парагенезис $(\mathrm{Qz}+\mathrm{Au}+\mathrm{Apy}+\mathrm{Po})$ 803,0 $\pm 6,1-758,0 \pm 6,0$ млн лет; поздние золото-сурьмяные ассоциации 795.2 $\pm 5.8-660.0 \pm 19.0$ млн лет [Гибшер и др., 2019a, b]. По данным Новожилова Ю.И. и Гаврилова А.M. (Rb/Sr) слюдисто-кварц-карбонатные сланцы с ранней золото-мышьяковой минерализацией сформированы 794 \pm 15 млн лет, а для поздней золото-сурьмяной авторами установлен возраст в $615 \pm 15$ млн лет [Новожилов, Гаврилов, 1999]. Е.А. Наумов [Naumov et al., 2015] с соавторами получили возраст для игольчатого золото-содержащего арсенопирита $689 \pm 28$

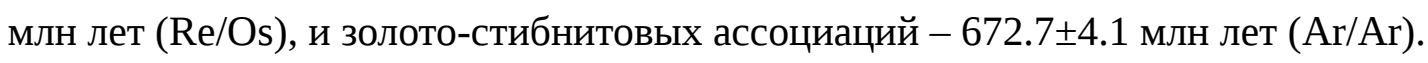
Полученные датировки рудного процесса позволяют говорить о том, что гидротермальная система месторождения эволюционировала на протяжении 150 млн лет.

\section{ОБРАЗЦЫ И МЕТОДЫ ИССЛЕДОВАНИЯ}

Пробы золота самородного, арсенопирита, пирротина, пирита и стибнита отобраны из керна разведочных скважин (разведочная линия 25.5) и карьера Восточного участка месторождения Олимпиада. Описание процесса подготовки проб приведено в работе [Сильянов и др., 2018].

Монофракции минералов подвергались тщательному изучению под электронным микроскопом для определения содержания основных элементов, а также диагностики микровключений. Исследования выполнены на приборах: микрозонд Jeol JXA-8100, ИГМ CO РАН, г. Новосибирск (аналитик В.Н. Королюк); СЭМ Tescan Vega III SBH с ЭДС 
Oxford X-Act, R\&D центр НорНикель ИГДГиГ СФУ, г. Красноярск (аналитик C.A. Сильянов); СЭМ Tescan Vega II LMU с ЭДС OXFORD INCA ENERGY 350, ЦКП «Аналитический центр геохимии природных систем», ТГУ, г. Томск (аналитик Е.В. Корбовяк, К.В. Бестемьянова).

Элементы-примеси определены методом ICP-MS на приборе Agilent 7500cx, производства Agilent Technologies. Предварительно навеска проб сульфидов и золота поступательным разложением переводилась в азотнокислый и царско-водочный растворы, что позволяло удержать в жидкой фазе и проанализировать максимально возможный спектр элементов. Качество полученных результатов оценивалось на основании стандартов горных пород и руд BCR-2, BHWO, ССЛ-1 и др. Анализы выполнены в ЦКП «Аналитический центр геохимии природных систем», ТГУ, г. Томск (аналитики Е.В. Рабцевич и Е.И. Никитина).

Анализ распределения REE в изученных минералах проводился на основе эталона хондрита (Cl) [McDonough, Sun, 1995], как наиболее часто применяющегося при анализе распределения лантаноидов в породах, рудах и минералах. Геохимия рассеянных элементов оценена относительно состава верхней коры (UC) [Rudnick, Gao, 2003] и гидротермально не измененных пород кординской свиты (Kd) [Лиханов и др., 2006] с целью изучения изменений, вызванных гидротермальным рудообразованием, в первичных вмещающих толщах. Нормирование на UC позволило выявить особенности протолита (пород корды) и показать дифференциацию элементов в рудном процессе. Баланс благородных металлов также оценен на основании состава верхней коры, для изучения влияния рудного процесса на породы протолита.

\section{РЕЗУЛЬТАТЫ ИССЛЕДОВАНИЯ}

Ниже приводится минералогическая характеристика, рассмотренных в статье образцов, и результаты изучения распределения редких и рассеянных элементов, а также благородных металлов в сульфидах и золоте месторождения Олимпиада.

Минералогическая характеристика изученных образцов. Арсенопириты разделены на ранний, игольчатый (образец № 4) и поздние - дипирамидальный и призматический (образцы №№ 1-3, 5-7) (Табл. 1). Рассмотренные образцы минерала характеризуются постоянным дефицитом катионов (Табл. 1). Соотношение анионов варьирует от наиболее стехиометричных разностей, где пропорции серы и мышьяка стремятся к 1:1 (образцы №№ 1 и 7), до крайне нестехиометричных с преобладанием серы (образцы №№ 2, 4, 5) или мышьяка (образцы №№ 3 и 6). Отклонение от стехиометрии фиксируется и Мёссбауэровским исследованием [Сазонов и др., 2016; Кирик и др., 2017; Sazonov et al., 2019], показывающим, что доля атомов железа с собственно арсенопиритовым окружением $\left\{\mathrm{FeAs}_{3} \mathrm{~S}_{3}\right\}$ изменяется от 54\% (обр. № 5) до 70\% (обр. № 7).

Пирит месторождения имеет близкий к стехиометричному состав (Табл. 1). Для ряда образцов отмечается примесь никеля и/или кобальта (обр. №№ 8, 11, 12), реже в составе минерала присутствует мышьяк (обр. №№ 10 и 11). Мессбауэровская спектроскопия на ядрах ${ }^{57} \mathrm{Fe}$ показывает, что основная часть (в среднем 93\%) атомов железа находится в окружении, соответствующем минералу.

Пирротины по химическому составу близки к моноклинной разновидности и рассчитываются на формулу $\mathrm{Fe}_{7} \mathrm{~S}_{8}$, с незначительными вариациями в катионной части (Табл. 1). 
Изученный образец стибнита показывает высокую стехиометрию, формула, рассчитанная по среднему химическому составу ( $n=24, \mathrm{~S}=29.14$ и $\mathrm{Sb}=73.75$ мас.\%), имеет вид $\mathrm{Sb}_{2} \mathrm{~S}_{3}$ (Табл. 1).

Самородное золото, рассматриваемое в данной работе, отвечает высокой пробности (899-1000\%о) и характеризуется примесью только серебра, в количестве до 10\% (см. Табл. 1).

Температуры образования арсенопирита, определенные по геотермометру Кретчмара и Скотта [Kretschmar, Scott, 1976; Scott, 1983] изменяются в интервале 300$460^{\circ} \mathrm{C}$, при вариации фугитивности серы $\log \alpha \mathrm{S}_{2}=-14.6 \ldots-5.9$, а формирование пирротина происходило при большей температуре $-419-502^{\circ} \mathrm{C}$, парциальное давление серы составляло $\log \alpha \mathrm{S}_{2}=-6.5 \ldots-4.4$ [Toulmin, Barton, 1964; Lambert et al., 1998]. Температуры кристаллизации сульфидов, в целом, соответствуют температурам, оцененным по флюидным включениям в кварце для ранних ассоциаций.

Электронно-микроскопическое изучение зерен минералов из проб, рассмотренных в данной работе, показывает наличие микровключений (Табл. 1).

Распределение рассеянных элементов. Для пород кординской свиты на удалении от рудных объектов [Лиханов и др., 2006] характерно близкларковое (относительно состава верхней коры (UC) по [Rudnick, Gao, 2003] содержание Rb, Ba, Ta, Zr, Nb, Hf, Ho, Th, U, Y и слегка пониженные концентрации никеля, кобальта и стронция (Рис. 2).

Большинство рассматриваемых образцов характеризуются наличием (относительно других элементов) положительных аномалий $\mathrm{Ni}, \mathrm{Co}, \mathrm{W}, \mathrm{Sn}$ и отрицательных $\mathrm{Cr}, \mathrm{Rb}, \mathrm{Sr}, \mathrm{Ba}$, $\mathrm{V}$ (Рис. 2, Табл. 2). Для никеля и кобальта свойственно существенное накопление в сульфидах относительно UC и неизмененных пород кординской свиты. Исключение составляют образцы арсенопирита № 1, пирита № 9, 11, пирротина № 13 и стибнита № 78, где содержания Ni и Со варьируют от близкларковых (UC и породы корды) до слабо обогащенных и обедненных по сравнению с UC и вмещающими породами. Для золота самородного в отличии от сульфидов характерно существенное (примерно на порядок) обеднение никелем и кобальтом относительно кларка (Рис. 2, а). Олово концентрируется во всех рассмотренных образцах примерно в равных количествах на уровне кларковых содержаний (UC).

Поведение вольфрама, в целом схоже, и отличается преимущественной концентрацией в рассматриваемых образцах. Для ряда проб характерно близкларковое (UC) содержание элемента (№№ 1, 2, 3, 4, 8, 13, 14 ,15, 45-3). Самородное золото (46-3), пирротин (16) и стибнит (78) характеризуются пониженными концентрациями тугоплавкого элемента ( на порядок относительно UC). По данным Л. Куна с соавторами для арсенопиритов месторождения золота Жеванг (Китай) установлено обогащение вольфрамом, что авторы связывают с деятельностью магматогенных флюидов [Kun et al., 2014]. С другой стороны, H.Н. Баранова с коллегами, при изучении Au-Sb-W минерализации Олимпиады предположили, что увеличение количества вольфрама во флюиде связано с увеличением его солености, а также с уменьшением мольной доли $\mathrm{N}_{2}$ [Баранова и др., 1997], что также может влиять на баланс элемента в изученных минералах.

Хром, рубидий, стронций, барий и ванадий показывают удивительно стабильную тенденцию к деплетированию в рудных минералах месторождения. Их концентрации во всех образцах ниже таковых для верхней коры на 1-3(4) порядка. Относительно вмещающих пород кординской свиты прослеживается такая же тенденция для Rb, Sr и Ba, 
при этом, в породах корды устанавливается относительное преобладание рубидия над стронцием, а в рудных минералах прослеживается обратная тенденция.

Халькофильные элементы $\mathrm{Cu}, \mathrm{Pb}, \mathrm{Bi}, \mathrm{Zn}$ отличаются дифференцированным поведением. В большей части образцов они проявляют тенденцию к накоплению относительно UC, либо показывают близкие к ней содержания. Как правило, устанавливается доминирование концентрации висмута относительно $\mathrm{Cu}, \mathrm{Pb}$ и $\mathrm{Zn}$, за исключением образцов арсенопирита № 3, пирита № 10, 11, 12, золота № 45-3 и стибнита № 78. Соотношения меди и свинца сильно варьируют. Цинк как правило ведет себя стабильно, показывая в основном близкларковые (либо слегка пониженные) содержания относительно UC, исключением является образец пирита № 12 для которого установлены максимальные концентрации элемента (Табл. 2, Рис. 2, с).

Высокозарядные элементы (Ta, Zr, Nb, Hf, Ho, Th, U, Y) характеризуется наиболее разнообразным поведением. В целом для них характерно стабильное деплетирование относительно состава верхней коры, в то время как вмещающие породы кординской свиты отличаются близкларковыми содержаниями. Выделяется группа рудных минералов со схожим распределением HFSE относительно пород кординской свиты, они (арсенопирит № 1, 2, 5; пирит № 8, 9; пирротин № 13, 16) характеризуются прямолинейным трендом содержаний Ta, Zr, Nb, Hf, Ho, Th, U, Y, для остальных образцов отмечается пилообразное распределение указанных элементов. По поведению гольмия можно выделить две группы. Первая характеризуется его положительной аномалией (арсенопириты № 3, 6; пириты № 8, 10, 11, 12; пирротины № 13-16; золото № 46-3; стибнит № 78), для остальных образцов гольмий не проявляет признаков фракционирования. Стоит также отметить наличие существенных положительных аномалий тантала и ниобия для самородного золота месторождения (Рис. 2, а), для сульфидов подобные аномалии не характерны (Рис. 2, b-d).

Распределение редкоземельных элементов. Общее содержание редкоземельных элементов в рассмотренных образцах изменяется от 0.99-1.70 до 41.15-65.59 ppm (Табл. 3). По средним значениям наблюдается тренд снижения концентраций REE от стибнита (41.15 ppm) к арсенопириту (19.65 ppm), пириту (14.16 ppm) и пирротину (3.46 ppm). Для золота самородного устанавливаются широкие вариации $\Sigma \mathrm{REE}$ (1.4-65.59 ppm). В рассмотренных образцах основная доля приходится на LREE (73-99\%), а среди остальных лантанидов преобладают MREE, за исключением самородного золота (№ 46-3) и стибнита (№ 78), где проявлена тенденция накопления HREE относительно MREE (Табл. 4).

Ранее нами отмечалась корреляция между количеством микровключений и концентрациями REE в минерале [Сильянов и др., 2018]. Анализ взаимоотношения суммы примесей и относительного количества минеральных включений в рассмотренных образцах показывает подобную тенденцию. Наиболее богат включениями арсенопирит, а остальные минералы более свободны от них, что согласуется с данными о суммарных содержаниях лантанидов. Повышенные концентрации REE в стибните могут быть в свою очередь связаны с процессом вовлечения в образование сурьмяных парагенезисов флюида иного источника, который по данным 3.Б. Афанасьевой с соавторами мог быть значительно обогащен лантанидами относительно раннего флюида [Афанасьева, и др., 1997]. Стоит отметить, что арсенопирит в рудах месторождений Енисейского кряжа проявлен в виде метакристаллов и футляровидных образований. Нами отмечена тенденция концентрирования арсенопиритом минералов, содержащих редкие и рассеянные элементы (циркон, монацит, торит, апатит). 
При нормировании на хондрит [McDonough, Sun, 1995] большинство рассмотренных минералов характеризуются пологой формой распределения REE, c преобладанием LREE над HREE ( $\Sigma \mathrm{LREE} / \Sigma \mathrm{HREE}=3.38-13.18 ; \mathrm{La}_{\mathrm{n}} / \mathrm{Yb}_{\mathrm{n}}=4.14-35.41$ ) и равномерным распределением $\operatorname{HREE}\left(\mathrm{Gd}_{\mathrm{n}} / \mathrm{Yb}_{\mathrm{n}}=0.60-2.23\right)$ (Табл. 3, 4, Рис. 3). Подобная форма хондрит-нормированных спектров и низкие содержания лантанидов могут указывать на вовлечение в процесс рудообразования метаморфогенного флюида [Горячев и др., 2008; Волков и др., 2016]. Наиболее крутой наклон спектров отмечается для образцов золота самородного (№ 46-3), арсенопирита (№ 3), пирротина (№ 16) и стибнита (№ 78). Отношения $\Sigma \mathrm{LREE} / \Sigma \mathrm{HREE}$ и $\mathrm{La}_{\mathrm{n}} / \mathrm{Yb}_{\mathrm{n}}$ для них изменяются в пределах 13.19-105.75 и 28.66-2320.24, соответственно. Для этих образцов также свойственно сильное фракционирование HREE $\left(\mathrm{Gd}_{\mathrm{n}} / \mathrm{Yb}_{\mathrm{n}}=1.74-32.11\right)$.

Регионально-метаморфизованные рудовмещающие породы кординской свиты, не затронутые гидротермальным процессом, характеризуются более высокой суммой редкоземельных элементов (340.45 ppm); пологим трендом снижения концентраций REE в ряду от La до Lu ( $\left.\Sigma \mathrm{LREE} / \Sigma \mathrm{HREE}=10.29 ; \mathrm{La}_{\mathrm{n}} / \mathrm{Yb}_{\mathrm{n}}=12.84\right)$; равномерным распределением HREE $\left(\mathrm{Gd}_{\mathrm{n}} / \mathrm{Yb}_{\mathrm{n}}=1,86\right)$ (данные о концентрациях Р3Э в неизмененных породах кординской свиты взяты из работы [Лиханов и др., 2006], среднее по двум образцам Е-8 и Е-10). Относительно вмещающих пород все рассмотренные сульфиды и золото значительно деплетированы REE (Рис. 3). Форма спектров большинства рассмотренных образцов в целом сходна с распределением лантанидов в породах кординской свиты, что может указывать на вынос металлов из пород при рудообразовании [Kun et al., 2014]. Однако, спектры образцов арсенопирита №№ 2, 3, 4 и самородного золота №46-3 значительно отличаются от таковых для вмещающих пород (Рис. 3). Обращает на себя внимание арсенопирит (№ 6), отношения $\Sigma \mathrm{HREE} / \Sigma \mathrm{REE}=0.22$, $\Sigma \mathrm{LREE} / \Sigma \mathrm{HREE}=3.38$ и Sm/Nd=0.25 которого близки нижнекоровым ( $\Sigma \mathrm{HREE} / \Sigma \mathrm{REE}=0.23$, $\Sigma \mathrm{LREE} / \Sigma \mathrm{HREE}=3.28$ и $\mathrm{Sm} / \mathrm{Nd}=0.25$ ). Стибнит характеризуется наиболее отличной формой хондрит-нормированного спектра. Минерал имеет отчетливую омега-образную форму спектра с преобладанием La-Pr и GdDу (Рис. 3, Табл. 3, 4).

Подобные результаты были получены З.Б. Афанасьевой с коллегами при изучении REE-систематики в шеелитах Олимпиады [Афанасьева, и др., 1997]. Авторы показывают, что на месторождении выделяется две группы минерала, первая, ассоциирующая с золотоарсенопиритовой минерализацией, характеризуется низкими содержаниями лантанидов и плоским графиком распределения хондрит-нормированных значений. Для второй группы шеелитов в ассоциации с сурьмяными парагенезисами, характерно высокое содержание MREE, которое проявлено в виде «горба» на хондрит-нормированном спектре, аналогично, спектрам, показанным в нашей работе для стибнита.

При нормировании содержаний REE в сульфидах и золоте на состав неизмененных пород кординской свиты происходит выполаживание спектров арсенопиритов (№№ 1 и 7) и пирротина (№№ 13, 15), а также самородного золота (№ 45-3), в численном отношении это выражается в приближении к единице значений $\mathrm{La}_{n} / \mathrm{Yb}_{\mathrm{n}}=0.84-1.34 ; \mathrm{La}_{\mathrm{n}} / \mathrm{Sm}_{\mathrm{n}}=0.94-1.78$ и $\mathrm{Gd}_{\mathrm{n}} / \mathrm{Yb}_{\mathrm{n}}=0.75-1.20$, соответственно (Табл. 4, Рис. 4), что может предполагать наследование состава REE вмещающих пород [Борисов и др., 2011]. Спектры остальных образцов проявляют тенденцию к концентрированию HREE. Исключение составляют: образец самородного золота (№ 46-3), форма спектра которого в области La-Eu носит плоский характер, а от Eu до Lu не отличается от значений, нормированных на хондрит; образец пирита (№ 9), отличие которого от спектра, нормированного на $\mathrm{Cl}$, заключается в более 
низких значениях лантанидов от Се до Dy; образец арсенопирита (№ 3) и стибнита (№ 78) спектры которых практически идентичны спектрам значений, нормированных на хондрит (Рис. 4).

Выявленные REE паттерны предполагают превалирующее участие корового вещества при образовании ранних ассоциаций и привнос вещества из иного источника для поздних сурьмяных парагенезисов. Однако, REE-спектры ранних минералов дают указание на возможность вовлечения в рудообразование вещества из другого, возможно, глубинного источника, что указывает на полигенность рудного материала не только ранних и поздних стадий, но и каждой из них в отдельности.

На полигенность рудного вещества могут указывать и величины Sm/Nd отношения, которые варьируют в пределах 0.17-0.27 (Табл. 4) и для большинства образцов приближаются к таковым для верхней коры (UC=0.17), однако образцы арсенопирита (№ 6), пирита (№ 10), пирротина (№ 14) и, в меньшей мере, пирита № 11 и стибнита № 78, характеризуются значением $\mathrm{Sm} / \mathrm{Nd}$ близким к таковому в нижней коре ( $\mathrm{LC}=0.25)$.

Также, единично установлены слабые тетрадные эффекты (ТЕ) фракционирования REE в третьей (TE3) и четвертой (TE4) тетраде (Табл. 4, Рис. 3) (величины TE3 и TE4 рассчитаны по уравнениям из работы [Monecke et al., 2002b]). Для образца самородного золота 46-3 установлены слабые ТЕ3 М типа и W типа для TE4. Для арсенопирита (№ 7) и пирротина (№ 13) характерен TE3 W типа. Стибнит (№ 78) характеризуется TE3 и TE4 M типа (Рис. 3). Присутствие подобных эффектов можно связать с магматической или высокотемпературной дифференциацией вещества [Monecke et al., 2002b]. Наличие фракционирования в четвертой тетраде может быть объяснено появлением аномалии тулия, которая диагностирована для стибнита (№ 78) с положительным знаком $(\mathrm{Tm} / \mathrm{Tm} *=1.32)$ и золота самородного (№ 46-3) с отрицательным $(\mathrm{Tm} / \mathrm{Tm} *=0.89)$. Отрицательная аномалия тулия $\left(\mathrm{Tm} / \mathrm{Tm}^{*}=0.89\right)$ проявлена и для пирротина № 16 , однако, величина TE4 для образца не столь высока. Положительная аномалия тулия была отмечена ранее А.Н. Некрасовой с соавторами для самородного золота Енисейско-ВосточноСаянской провинции [Некрасова и др., 2010] и нами для пирротина месторождения Панимба [Сильянов и др., 2018].

При анализе взаимоотношения суммы REE и величины Eu аномалии был выявлен слабый отрицательный тренд зависимости этих величин для образцов арсенопирита месторождения Олимпиада. Данный тренд теряется при добавлении на график образцов сульфидов железа, стибнита и золота самородного, и не проявлен в отдельности для этих минералов. Подобная зависимость характерна для магматических образований и отмечена Н.А. Горячевым с соавторами для метасоматитов Наталкинского месторождения, рудообразующие флюиды которого являются преимущественно магматическими [Горячев и др., 2008].

Аномалии Eu и Се характеризуются значительными вариациям в знаке и в абсолютных значениях (Рис. 3, Табл. 4). Можно выделить следующие группы образцов по особенностям $\mathrm{Eu} / \mathrm{Eu}^{*}$ и $\mathrm{Ce} / \mathrm{Ce}$. Для первой характерны отрицательные аномалии европия $\left(\mathrm{Eu} / \mathrm{Eu}^{*}=0.46-0.82\right)$ и положительные церия (Ce/Ce*=1.09-1.18). Особенностью второй группы является наличие слабоположительной аномалии Се и значительно положительной $\mathrm{Eu}\left(\mathrm{Eu} / \mathrm{Eu}^{*}=1.70 ; \mathrm{Ce} / \mathrm{Ce} *=1.18\right)$. Третья отличается отрицательными аномалиями как европия, так и церия ( $\left.\mathrm{Eu} / \mathrm{Eu}^{*}=0.37-0.82 ; \mathrm{Ce} / \mathrm{Ce}^{*}=0.24-0.98\right)$. Подобные инверсии знаков и абсолютных значений аномалий европия и церия интерпретируются сменой редокспотенциала и кислотности/щелочности в процессе минералообразования [Прокофьев и 
др., 2010; Знаменский, 2017]. Положительная аномалия Eu, проявленная в образце пирротина № 14, может быть также объяснена поступлением порций флюида из нижних частей континентальной коры, которая обогащена $\mathrm{Eu}^{2+}$ [Taylor, McClennan, 1985], стоит отметить, что для этого образца отношение $\mathrm{Sm} / \mathrm{Nd}$ также близко к нижнекоровому. Положительные аномалии Еu могут также служить показателем высокотемпературного (>200-250² $)$ фракционирования лантаноидов [Bau, 1991].

Индикатором редокс-потенциала среды также является отношение $\mathrm{Th} / \mathrm{U}$, абсолютные значения которого в изученных образцах выше единицы и изменяются от 1.32 до 6.59, указывая на восстановительный характер флюида [Волков и др., 2016]. Результаты термобарогеохимических исследований позволяют говорить о том, что рудогенные флюиды имели окислительно-восстановительные характеристики, при этом на восстановительный характер флюида указывает высокое отношение алканов к алкенам во флюидных включениях в сульфидах (1.1-30.9) и пониженное содержание воды (особенно для флюидов, сформировавших Au-As минерализацию) во включениях в кварце, в то же время, увеличение доли воды во флюидных включениях, характерных для $\mathrm{Au}-\mathrm{Sb}$ ассоциаций, указывает на смену восстановительной обстановки окислительной [Гибшер и др., 2019, b].

Полученные данные о распределении REE и HFSE позволяют говорить о том, что сульфиды и золото преимущественно концентрируют легкие лантаниды, но деплетированы HFSE, на что указывают отношения $\mathrm{Hf} / \mathrm{Sm}, \mathrm{Nb} / \mathrm{La}$ и Th/La, значения которых обычно меньше единицы (Табл. 4) (за исключением отношения Hf/Sm для некоторых образцов). Такое поведение REE и HFSE может указывать на то, что гидротермальный флюид был обогащен хлоридными комплексами [Kun et al., 2014]. Обогащение флюида фтором ведет к одновременному концентрированию REE и HFSE, при этом отношения $\mathrm{Hf} / \mathrm{Sm}, \mathrm{Nb} / \mathrm{La}$ и Th/La становятся больше единицы. Такая тенденция отмечена для образца самородного золота (№45-3), для которого Hf/Sm=7.92 и $\mathrm{Nb} / \mathrm{La}=10.46$ максимальны; отношение Th/La здесь меньше единицы (0.39), однако оно является одним из наиболее высоких для всех образцов. Недавние исследования флюидных включений в жильном кварце месторождения показывают наличие только хлоридных комплексов [Гибшер и др., 2019b], подобные результаты получены и в более ранних исследованиях [Прокофьев и др., 1994; Баранова и др., 1997; Генкин и др., 2002]. Однако, прецизионные определения состава газовой фазы флюидных включений в кварце и сульфидах, выполненные методом газовой хромато-масс-спектрометрии [Гибшер и др., 2019b], устанавливают наличие таких фтор-содержащих углеводородов, как 1-фторбутан $\left(\mathrm{C}_{4} \mathrm{H}_{9} \mathrm{~F}\right)$ и 1.1-дихлор-1-фторэтан $\left(\mathrm{C}_{2} \mathrm{H}_{3} \mathrm{Cl}{ }_{2} \mathrm{~F}\right)$, что согласуется с полученными нами данными.

Отношения $\mathrm{Co} / \mathrm{Ni}$ в рассматриваемых образцах изменяются от 0.12 до 61.73 (Табл. 4). Можно выделить образцы с Co/Ni отношением меньше 1 , что демонстрирует относительно низкую температуру минералообразования; с Co/Ni отношением близким к 1, для этих образцов предполагается средняя температура образования; и с Co/ $\mathrm{Ni}$ отношением больше 1 , что свидетельствует о высокой температуре минералообразования и о возможном влиянии магматических гидротерм [Kun et al., 2014].

Распределение благородных металлов. Содержание золота и серебра в сульфидах месторождения изменяется в пределах 0.1-93.7 и 0.1-23.3 ppm, соответственно (Табл. 5). Максимальные концентрации Аu отмечены для образцов арсенопирита №№ 4 и 5, а серебра для пирита № 11 и пирротина № 13. Интересной особенностью является 
доминирование концентраций серебра над золотом для большинства рассмотренных образцов сульфидных минералов, а также отсутствие корреляции между этими элементами. Au/Ag отношение (Табл. 5) как правило меньше единицы (0.01-0.69) и только в ряде образцов приобретает значения в интервале 1.6-83.1, при этом для самородного золота первичных руд данное отношение варьирует в пределах 6.51->1000 (в среднем 31.06), а окисленных - 6.49->10000 (в среднем 70.48) [Бернатонис, 1999]. Для коренных руд установлено среднее значение $\mathrm{Au} / \mathrm{Ag}$ равное 2.24 (по данным П.В. Бернатониса [1999] $\mathrm{Au} / \mathrm{Ag}$ в первичных рудах варьирует в диапазоне 0.4-80), а для окисленных - 5.20 [Совмен и др., 2009].

Н.Н. Баранова с соавторами, на основании данных о концентрации золота во флюидных включениях в условиях пирит-пирротинового буфера при pH 5.5-6 предполагают существование золота в виде бигидросульфидного комплекса $\mathrm{Au}(\mathrm{HS})^{-}{ }_{2}$ [Баранова и др., 1997]. Г.А. Пальянова на основе термодинамических расчетов и анализа большого количества литературных данных показала, что образование самородного золота на месторождениях золото-мышьяковистого (Олимпиада) и золото-сурьмяного (Удерей) типа может происходить при эволюции флюида от щелочного разной солености умеренной-высокой $\left(200-500^{\circ} \mathrm{C}\right)$ температуры с преобладанием бигидросульфидных комплексов $\mathrm{Au}(\mathrm{HS})_{2}^{-}$и $\mathrm{Ag}(\mathrm{HS})_{2}^{-}$на ранних стадиях, до слабокислого близнейтрального среднесоленого умеренно-высокой $\left(200-400^{\circ} \mathrm{C}\right)$ температуры с хлоридными комплексами серебра $\left(\mathrm{AgCl}_{2}^{-}\right)$и бигидросульфидными комплексами золота (Au(HS) $\left.{ }_{2}\right)$ - на поздних [Pal'yanova, 2008]. При этом характерны высокие Au/Ag отношения для самородного золота (2-1000) и руды в целом (0.1-30), а также флюида, что хорошо согласуется с

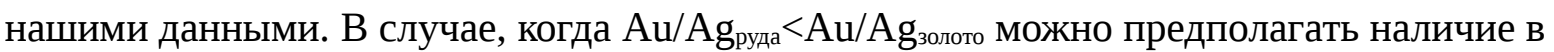
рудах минералов серебра [Pal’yanova, 2008; Liang, Hoshino, 2015; Пальянова и др., 2019].

Для большинства рассмотренных сульфидов характерно преобладание серебра над золотом, а Au/Ag отношение при этом изменяется от 0.01 до 0.69 (Табл. 5), что ниже, чем в первичных и окисленных рудах, а также самородном золоте месторождения. Если предположить, что в балансе концентраций золота и серебра в сульфидах с $\mathrm{Au} / \mathrm{Ag}<1$ роль металлов находящихся в растворе во флюидных включениях пренебрежительно мала, а по данным микроскопического изучения в большинстве образцов отсутствует видимое золото (см. Табл. 1), то металл находится в «невидимой» форме. А при значениях $\mathrm{Au} / \mathrm{Ag}<20$ можно также предполагать наличие микро и нано частиц, в которых преобладает серебро, это могут быть как самородные так и сульфидные формы благородных металлов [Пальянова и др., 2019]. Подобное поведение золота и серебра в сульфидных минералах показано нами ранее для месторождений Панимба и Советское [Сильянов и др., 2018; Пальянова и др., 2019].

При отсутствии корреляции золота и серебра с сурьмой и висмутом (элементами, с которыми эти металлы могут образовывать минеральные фазы) наиболее вероятно присутствие именно сульфидов благородных металлов (петровскаит, ютенбогаардтит), либо сплавов $\mathrm{Au}_{\mathrm{x}} \mathrm{Ag}_{1-\mathrm{x}}$. Однако, отсутствие корреляции между золотом и серебром в изученных образцах предполагает существование либо микро и нано размерных образований электрума или кюстелита, либо разных минералов для золота и серебра (к примеру, акантита и металлического золота). Стоит отметить, что за всю историю изучения Олимпиадинского месторождения, данные о наличии сульфидов серебра представлены только в работе П.В. Бернатониса [Бернатонис, 1999], что подтверждает 
наличие именно микронных или нано размерных частиц сульфидов серебра и/или золота, трудных для обнаружения.

Среди элементов платиновой группы (Pt, Pd, Ru) преобладает палладий, концентрации которого примерно на порядок выше концентраций платины, и на два порядка - рутения (Табл. 5). По соотношению этих элементов прослеживается увеличение содержания платины в ряду пирит-арсенопирит-золото-пирротин-стибнит (Рис. 5, b). Пирротины и стибнит характеризуются повышенными содержаниями рутения (Рис. 5, b). $\mathrm{Pt} / \mathrm{Pd}$ отношение в рассматриваемых образцах варьирует в пределах 0.03-0.65, и только в стибните превышает единицу (1.28), что можно рассматривать как указание на иной источник металлов при формировании сурьмяной минерализации.

Нормированные на состав верхней коры [Rudnick, Gao, 2003] содержания благородных металлов (в том числе и PGE) показывают сходные паттерны распределения (Рис. 5, а) с тенденцией к накоплению относительно UC (в 10-1000 раз и более) и преобладанием в общем балансе золота, серебра и палладия. Недавнее исследование содержаний PGE и Re во флюидных включениях в сульфидах Олимпиадинского месторождения, проведенное Н.А. Гибшер с соавторами показывает сходные результаты. Авторами установлено, что во флюидных включениях в сульфидах концентрации PGE увеличены (за исключением Re) до 10-100 относительно верхней коры [по Rudnick, Gao, 2003], а распределение нормированных значений однотипно и характеризуется вариациями концентраций [Гибшер и др., 2018]. Относительно распределения Pt, Pd и Re авторами установлено два тренда: первому соответствуют флюиды, обогащенные Pt и Pd, для второго определены повышенные концентрации рения, которые авторы связывают с углеродсодержащими сланцами месторождения [Гибшер и др., 2018]. По мнению авторов, в процессе рудообразования, благородные металлы (Au, Ag) отлагались в минеральную фазу, а PGE и Re остались во флюидных включениях. Исходя из полученных нами данных, для рассматриваемых образцов характерна положительная корреляция в группе платиноидов, но при этом между PGE и золотом, и серебром подобные связи отсутствуют. Такое поведение благородных металлов может указывать на разный источник этих металлов, либо на разные механизмы их концентрирования сульфидами.

\section{ОБСУЖДЕНИЕ РЕЗУЛЬТАТОВ}

Данные о распределении REE, различие в концентрировании PGE, а также ряд индикаторных отношений могут указывать минимум на два главных источника вещества при формировании минерализации месторождения. Первый из них связан с коровым веществом ( $\mathrm{UC} \pm \mathrm{LC})$, второй характеризуется большей глубинностью. На разные источники вещества указывают и данные 3.Б. Афанасьевой и коллег. На основании изучения распределения REE в шеелите месторождения авторы показывают, что шеелиты из разных ассоциаций (Au-As и $\mathrm{Au}-\mathrm{Sb}$ ) образовались из флюидов, имеющих разные источники, более ранний из которых был обеднен, а более поздний обогащен лантаноидами [Афанасьева, и др., 1997].

Можно предполагать эволюцию доминирующих источников вещества, а также их смешение при рудообразовании. Так, ранние золото-мышьяковистые парагенезисы могут быть сформированы при превалирующем участии верхнекорового вещества, о чем говорят спектры распределения REE рудных минералов, идентичные вмещающим породам. При нормировании на состав кординской свиты эти спектры проявляют тенденцию к выполаживанию. В пользу корового вещества говорят и $\mathrm{Sm} / \mathrm{Nd}$ отношения ряда образцов, 
близкие к значениям UC. Эти данные хорошо согласуются с изотопно-геохимическими свидетельствами. Так, А.А. Савичевым с соавторами и С.Г. Кряжевым получены данные по изотопному составу свинцов рудных минералов, указывающие на верхнекоровый источник вещества при формировании ранних парагенезисов [Савичев и др., 2006; Кряжев, 2017]. К подобным выводам пришли и Е.А. Наумов, а также А.С. Якубчук с коллегами при изучении ${ }^{187} \mathrm{Os} /{ }^{188} \mathrm{Os}$ систематики арсенопирита и пирротина месторождения [Yakubchuk et al., 2014; Naumov et al., 2015]. На преобладание корового вещества в рудной системе указывает отрицательное $\varepsilon_{\mathrm{Nd}}$ шеелитов месторождения [Савичев и др., 2006], при этом наибольшая степень контаминации коровым веществом характерна для шеелита в ассоциации с ранней золото-сульфидной минерализацией. Изучение изотопов гелия флюида, сформировавшего ранние парагенезисы, также говорят о его коровой природе [Naumov et al., 2015; Кряжев, 2017].

В тоже время, наши данные предполагают участие в формировании ранних ассоциаций иного источника вещества. Так, устанавливаются отличия в распределении REE от состава вмещающих пород, что говорит о дифференциации вещества, и может указывать на привнос его из другого источника. Для ряда образцов установлены значения отношений Sm/Nd, $\Sigma$ HREE/ $\Sigma$ REE и $\Sigma$ LREE/ $\Sigma$ HREE близкие к нижнекоровым. На участие более глубинного вещества указывают и наличие тетрадных эффектов фракционирования лантанидов, а также обратная корреляция суммы REE и Eu/Eu*, характерная для арсенопиритов месторождения. В пользу контаминации говорит и вариация в значении $\delta^{34} \mathrm{~S}$ ранних сульфидов [Кряжев, 2017; Гибшер и др., 2019, b].

Совершенно другой облик имеет поздняя сурьмяная минерализация. Наши данные о явно контрастном распределении лантаноидов и PGE в минералах сурьмы указывают на иной источник вещества при их формировании. Наличие ярко выраженных TE REE для стибнита может предполагать магматическую дифференциацию вещества при его образовании. На более глубинную природу вещества указывает и $\mathrm{Sm} / \mathrm{Nd}$ отношение, приближающееся к нижнекоровому. Подобные результаты получены Е.А. Наумовым с соавторами, которые показали, что значения ${ }^{187} \mathrm{Os} /{ }^{188} \mathrm{Os}$ минералов сурьмы указывают на мантийный источник [Naumov et al., 2015]. По данным А.А. Савичева с соавторами и С.Г. Кряжева изотопный состав свинца минералов Au-Sb ассоциаций ложится на линию смешения мантийных и коровых свинцов [Савичев и др., 2006; Кряжев, 2017]. Изучение изотопов серы также показывает автономность источника сурьмы и серы сульфидной при образовании поздних ассоциаций, при этом вклад глубинного источника здесь более значительный [Кряжев, 2017]. На мантийную природу флюида указывает и изотопный состав гелия включений в кварце с игольчатым арсенопиритом и стибнитом, а также в самом стибните, который по данным Е.А. Наумова с коллегами имеет мантийный состав [Naumov et al., 2015]. Преобладание глубинного, мантийного вещества при образовании сурьмяных парагенезисов, не исключает контаминацию или вовлечение в рудный процесс корового вещества, в пользу чего свидетельствуют данные Н.А. Гибшер с соавторами о коровом составе гелия во флюидных включениях в кварце золото-сурьмяных ассоциаций [Гибшер и др., 2019b], контрастирующие с результатами Е.А. Наумова.

Вслед за Н.А. Гибшер мы предполагаем, что в формировании рудной минерализации принимали участие (одновременно или последовательно) как минимум два флюида - водно-углекислотный и углекислотно-углеводородный [Гибшер и др., 2019b]. Исходя из полученных нами данных, можно предполагать, что в образовании рудной минерализации месторождения принимал участие существенно водный флюид средних до 
высоких температур, содержащий, в основном хлоридные комплексы, однако нельзя исключать наличия фторидов в растворе, о чем говорит поведение REE и HFSE, а также прецизионные определения фтор-содержащих углеводородов в кварце и сульфидах. Окислительно-восстановительные условия в процессе рудообразования изменялись от восстановительных при отложении золото-мышьяковистых парагенезисов до окислительных на поздней сурьмяной стадии. Нельзя исключать также вариации редокспотенциала внутри стадий, о чем можно судить по изменениям аномалий европия и церия. C другой стороны, полученные данные о Th/U отношении в сульфидах и золоте предполагают их образование в востановительной среде, что согласуется с данными определения отношения алканов к алкенам во флюидных включениях в сульфидах [Гибшер и др., 2019b]. О преобладании восстановительных обстановок говорят и данные определения углеводородов во включениях в кварце, самородном золоте и сульфидах месторождений кряжа, которые показывают увеличение доли углеводородов в ряду кварцсульфиды-золото [Бульбак и др., 2018].

Таким образом, предполагается, что ранняя продуктивная минерализация может быть сформирована, преимущественно коровым веществом, с незначительной долей нижнекорового и глубинного материала, что, видимо, является характерным для месторождений Енисейского кряжа, поскольку подобные закономерности были обнаружены нами ранее при анализе источников вещества месторождения Панимба [Сильянов и др., 2018]. В тоже время, уникальность Олимпиадинского месторождения обусловлена участием в рудоотложении существенно газовых восстановленных флюидов, а также наличием поздних сурьмяных стадий, несущих золотую минерализацию. Подобные парагенезисы проявлены не на всех месторождениях Енисейского кряжа, и образованы, вероятно, за счет более глубинного источника. В общем виде, целью дальнейших работ, по нашему мнению, должна являться более детальная оценка доли глубинного вещества, участвующего при образовании разновозрастных парагенезисов месторождения, а также интерпретация геологических процессов, связанных с подобным веществом.

\section{ЗАКЛЮЧЕНИЕ}

На основании полученных данных, а также анализа литературных источников, можно предположить следующее.

1. Различные тренды поведения примесных элементов в минералах ранних и поздних сульфидных ассоциаций позволяют предполагать различный источник образования золото-мышьяковистых и золото-сурьмяных парагенезисов руд месторождения. При этом, на основании характера распределения REE, «коровых» значений $\mathrm{Sm} / \mathrm{Nd}$ отношения и ряда других признаков, характерных для ранних сульфидов, можно предполагать их образование при превалирующем участии корового вещества. Происхождение сурьмяной минерализации, вероятно, связано со сменой основного источника рудного вещества на более глубинный, на что может указывать резко-отличное распределение REE и PGE в сурьмяных минералах месторождения. Полученные данные согласуются с ранее выполненными изотопными исследованиями, указывающими на различный (собственный) источник вещества мышьяковистых и сурьмяных ассоциаций месторождения;

2. В процессе рудообразования была возможна смена окислительновосстановительных условий, на что может указывать изменение содержаний $\mathrm{H}_{2} \mathrm{O}$ во 
флюидных включениях в кварце разных ассоциаций, а также вариации знаков и абсолютных значений европиевой и цериевой аномалий в рудных минералах. При этом $\mathrm{Th} / \mathrm{U}>1$ и отношение алканов к алкенам в сульфидах говорят о том, что в процессе их отложения система характеризовалась высоким редокс-потенциалом;

3. Хорошая сходимость данных о $\mathrm{Au} / \mathrm{Ag}$ отношении в самородном золоте и руде месторождения с термодинамическими расчетами стабильности различных комплексов благородных металлов в рудных флюидах позволяет предполагать, что Au и $\mathrm{Ag}$ присутствовали в виде бигидросульфидных комплексов. Это вместе с данными о повышенном содержании углеводородов в самородном золоте может предполагать транспорт металла восстановленными флюидами;

4. Анализ распределения элементов-примесей позволяет выделить два геохимических типа золота и арсенопирита. Для пирита и пирротина подобные различия менее проявлены. Наличие различных типов минералов по геохимии малых элементов может указывать на различные их генерации, либо на смену доминирующего источника вещества.

\section{БЛАГОДАРНОСТИ}

Исследование выполнено при финансовой поддержке РФФИ в рамках научного проекта № 19-35-90017 19, а также Правительства Российской Федерации (проект № 14.Y26.31.0012).

Авторы благодарят двух рецензентов за конструктивную критику и замечания, позволившие улучшить статью.

\section{СПИСОК ЛИТЕРАТУРЫ}

Афанасьева З.Б., Иванова Г.Ф., Румбо Л. Геохимия РЗЭ в породах и минералах шеелитсодержащего золото-сульфидного месторождения Олимпиада (Енисейский кряж) // Геохимия, 1997, №2, с. 189 - 201.

Баранова Н.Н., Афанасьева З.Б., Иванова Г.Ф., Миронова О.Ф., Колпакова Н.Н. Характеристика процессов рудообразования на $\mathrm{Au}-(\mathrm{Sb}-\mathrm{W})-$ месторождении Олимпиада (по данным изучения минеральных парагенезисов и флюидных включений) // Геохимия, 1997, №3, с. 282 - 293.

Бернатонис П.В. Зона окисления Олимпиадинского прожилково-вкрапленного золото-сульфидного месторождения. // Диссертация на соискание ученой степени кандидата геолого-минералогических наук, Томск, 1999, 184 с.

Борисов М.В., Волкова М.М., Бычков Д.А., Бычкова Я.В. Распределение редкоземельных элементов в рудных телах Джимидонского полиметаллического месторождения и вмещающих породах (северная Осетия, Россия) // Вестник московского университета. сер. 4. ГЕОЛОГИЯ, 2011. № 4, с. 48 - 52

Бульбак Т.А., Томиленко А.А., Сазонов А.М., Гибшер Н.А., Рябуха М.А., Хоменко М.О. Углеводороды флюидных включений в минералах руд месторождений золота Енисейского кряжа // Тезисы XVIII Всероссийской конференции по термобарогеохимии (100-летие Ю.А. Долгова). М. Минералогический музей им. А.Е. Ферсмана, 2018, c. $32-34$.

Волков А.В., Мурашов К.Ю., Сидоров А.А. Геохимические особенности руд месторождения золота Наталкинское - крупнейшего на северо-востоке России // Доклады академии наук, 2016, том 466, № 5, с. 574 - 577.

Генкин А.Д. Золотоносный арсенопирит из золоторудных месторождений: внутреннее строение зерен, состав, механизм роста и состояние золота // Геология рудных месторождений, 1998, Т. 40, № 6, с. 551 - 557. 
Генкин А.Д., Вагнер Ф.Е., Крылова Т.Л., Цепин А.И. Золотоносный арсенопирит и условия его образования на золоторудных месторождениях Олимпиада и Ведуга (Енисейский кряж, Сибирь) // Геология рудных месторождений. 2002, Т. 44. № 1, с. $59-77$.

Гибшер Н.А., Козьменко О.А., Томиленко А.А., Сазонов А.М., Рябуха М.А. Элементы платиновой группы и рений во флюидах Олимпиадинского золоторудного месторождения (Енисейский кряж, Россия) // Тезисы XVIII Всероссийской конференции по термобарогеохимии (100-летие Ю.А. Долгова). М. Минералогический музей им. А.Е. Ферсмана, 2018, с. 36 - 38.

Гибшер Н.А., Сазонов А.М., Травин А.В., Томиленко А.А., Пономарчук А.В., Сильянов С.А., Некрасова Н.А., Шапаренко Е.О., Рябуха М.А., Хоменко М.О. Возраст и продолжительность формирования Олимпиадинского золоторудного месторождения (Енисейский кряж, Россия) // Геохимия. 2019, Т. 64, № 5, с. 548 - 553, а

Гибшер Н.А., Томиленко А.А., Сазонов А.М., Бульбак Т.А., Рябуха М.А., Сильянов С.А., Некрасова Н.А., Хоменко М.О., Шапаренко Е.О. Олимпиадинское золоторудное месторождение (Енисейский кряж): температура, давление, состав рудообразующих флюидов, $\delta^{34} \mathrm{~S}$ сульфидов, ${ }^{3} \mathrm{He} /{ }^{4} \mathrm{He}$ флюидов, $\mathrm{Ar}-\mathrm{Ar}$ возраст и продолжительность формирования // Геология и геофизика, 2019, №9, с. 1310 - 1330, b

Горячев Н.А., Викентьева О.В., Бортников Н.С., Прокофьев В.Ю., Алпатов В.А., Голуб В.В. Наталкинское золоторудное месторождение мирового класса: распределение Р3Э, флюидные включения, стабильные изотопы кислорода и условия формирования руд (северо-восток России) // Геология рудных месторождений, 2008, Т. 50, № 5, с. $414-444$.

Знаменский С.Е. Редкоземельные элементы и иттрий в кальците и пирите Орловского месторождения золота (Южный Урал) // Литосфера, 2017, № 1, с. 135 - 141.

Кирик С.Д., Сазонов А.М., Сильянов С.А., Баюков О.А. Исследование разупорядочения в структуре природного арсенопирита рентгеноструктурным анализом поликристаллов и ядерным гамма-резонансом // Журнал Сибирского федерального университета, серия техника и технологии, 2017, 10(5), с. 578 - 592.

Кравцова Р.Г., Таусон В.Л., Никитенко Е.М. Формы нахождения золота, платины и палладия в арсенопиритах золоторудного месторождения Наталкинское (северо-восток России) // Геохимия, 2015, № 11, с. 991 - 999.

Кряжев С.Г. Генетические модели и критерии прогноза золоторудных месторождений в углеродисто-терригенных комплексах. // Диссертация на соискание ученой степени доктора геолого-минералогических наук, Москва, 2017, 288 с.

Ли Л.В. Олимпиадинское месторождение вкрапленных золото-сульфидных руд. Красноярск, КНИИГиМС, 2003, 117 с.

Лиханов И.И., Ревердатто В.В., Вершинин А.Е. Геохимические свидетельства природы протолита железисто-глиноземистых метапелитов кузнецкого Алатау и Енисейского кряжа // Геология и геофизика, 2006, т. 47, № 1, с. 119 - 131.

Некрасова А.Н., Николаева Л.А., Миляев С.А., Яблокова С.В. Первые данные о распределении $\mathrm{P} 3 Э, \mathrm{Li}, \mathrm{Rb}, \mathrm{Cs}, \mathrm{Sr}$, Ва в самородном золоте месторождений основных золотоносных провинций России // Доклады академии наук, 2010, том 432, № 5, с. $660-663$.

Новожилов Ю.И., Гаврилов А.М. Золото-сульфидные месторождения в углеродисто-терригенных толщах. Месторождение Олимпиадинское. М., ЦНИГРИ, 1999, 175 с.

Пальянова Г.А., Сазонов А.М., Журавкова Т.В., Сильянов С.А. Состав пирротина как индикатор условий минералообразования на золоторудном месторождении Советское (Енисейский кряж, Россия) // Геология и геофизика, 2019, №7, с. 934 - 354.

Петров В.Г. Условия золотоносности северной части Енисейского кряжа. Новосибирск, НАУКА, 1974, 138 с. 
Петров В.Г. Золото в опорных разрезах верхнего докембрия западной окраины Сибирской платформы. Новосибирск, НАУКА, 1976, 213 с.

Прокофьев В.Ю., Афанасьева З.Б., Иванова Г.Ф., Буарон М.К., Мариньяк Х. Исследование флюидных включений в минералах Олимпиадинского $\mathrm{Au}-(\mathrm{Sb}-\mathrm{W})-$ месторождения (Енисейский кряж) // Геохимия, 1994, № 7, с. 1012 - 1029.

Прокофьев В.Ю., Бортников Н.С., Коваленкер В.А., Винокуров С.Ф., Зорина Л.Д., Чернова А.Д., Кряжев С.Г., Краснов А.Н., Горбачева С.А. Золоторудное месторождение Дарасун (восточное Забайкалье, Россия): химический состав, распределение редких земель, изучение стабильных изотопов углерода и кислорода в карбонатах рудных жил // Геология рудных месторождений, 2010, том 52, № 2, с. 91 - 125.

Римская-Корсакова М.Н., Дубинин А.В. Редкоземельные элементы в сульфидах подводных гидротермальных источников Атлантического океана. // Доклады Академии наук, 2003, 389(5), с. $672-676$.

Савичев А.А., Шевченко С.С., Розинов М.И., Лохов К.И., Прасолов Э.М., Прилепский Э.Б., Капитонов И.Н., Матуков Д.И., Бережная Н.Г., Сергеев С.А. Изотопногеохимическая характеристика золото-сульфидного месторождения Олимпиада и его сателлитов (Енисейский кряж) // Региональная геология и металлогения, 2006, №28, с. $122-143$.

Сазонов А.М. Геохимия золота в метаморфических толщах. Томск, «ТПУ», 1998. 166 c.

Сазонов А.М., Ананьев А.А., Полева Т.В., Хохлов А.Н., Власов В.С., Звягина Е.А., Федорова А.В., Тишин П.А., Леонтьев С.И. Золоторудная металлогения Енисейского кряжа: геолого-структурная позиция, структурные типы рудных полей // Журнал Сибирского федерального университета. Серия Техника и Технологии, 2010, 4 (3), с. $371-395$.

Сазонов А.М., Кирик С.Д., Сильянов С.А., Баюков О.А., Тишин П.А. Типоморфизм арсенопирита золоторудных месторождений Благодатное и Олимпиада (Енисейский кряж) // Минералогия, 2016, № 3. с. 53 - 70.

Сазонов А.М., Звягина Е.А., Сильянов С.А., Лобанов К.В., Леонтьев С.И., Калинин Ю.А., Савичев А.А., Тишин П.А. Рудогенез месторождения золота Олимпиада (Енисейский кряж, Россия) // Геосферные исследования, 2019, № 1, с. 17 - 43.

Сильянов С.А., Сазонов А.М., Тишин П.А., Некрасова Н.А., Лобастов Б.М., Звягина Е.А., Рябуха М.А. Геохимические показатели генезиса месторождения золота Панимба в Енисейском кряже (Россия, Сибирь) // Геосферные исследования, 2018, № 3, с. 6 - 21.

Совмен В.К., Страгис Ю.М., Плеханов А.А., Бибик С.М., Кровякова Л.П., Савушкина С.И., Лохмаков В.А., Звездин И.Г., Логачев В.С. Геологическое строение золоторудных месторождений и опыт геологического обслуживания сырьевой базы компании Полюс в Красноярском крае. Красноярск, ООО «Версо», 2009, 208 с.

Таусон В.Л., Бабкин Д.Н., Пастушкова Т.М., Краснощекова Т.С., Лустенберг Э.Е., Белозерова О.Ю. Двойственные коэффициенты распределения микроэлементов в системе «минерал-гидротермальный раствор». І. Аккумуляция золота пиритом // Геохимия, 2011, № 6, с. 595 - 604 .

Barnes S.J., Liu W. Pt and Pd mobility in hydrothermal fluids: evidence from komatiites and from thermodynamic modelling // Ore Geology Reviews, 2012, 44, p. 49 - 58.

Bau M. Rare-earth element mobility during hydrothermal and metamorphic fluid-rock interaction and significance of oxidation state of europium // Chemical Geology, 1991, Vol. 93, p. $219-230$.

Borisenko A.S., Sazonov A.M., Nevolko P.A., Naumov E.A., Tessalina S., Kovalev K.R., Sukhorukov V.P. Gold Deposits of The Yenisei Ridge (Russia) and Age of Its Formation // Acta Geologica Sinica, 2014, Vol. 88, Supp. 2, p. 686 - 687. 
Cabri L.J., Newville M., Gordon R.A., Crozier E.D., Sutton S.R., McMahon G., Jiang DT. Chemical speciation of gold in arsenopyrite. // The Canadian Mineralogist, 2000, № 38, p. $1265-1281$.

Genkin A.D., Bortnikov N.S., Cabri L.J., Wagner F.E., Stanley C.J., Safonov Yu.G., McMahon G., Friedl J., Kerzin A.L., Gamyanin G.N. A multidisciplinary study of invisible gold in arsenopyrite from four mesothermal gold deposits in Siberia, Russian Federation. // Economic Geology, 1998, № 93(4), p. 463 - 487.

Guangzhou M., Renmin H., Jianfeng G., Weiqiang L., Kuidong Z., Guangming L., Huijuan L. Existing forms of REE in gold-bearing pyrite of the Jinshan gold deposit, Jiangxi Province, China // JOURNAL OF RARE EARTHS, 2009, Vol. 27, № 6, p. 1079 - 1087.

Kretschmar, U., Scott, S.D. Phase relations involving arsenopyrite in the system Fe-As-S and their application // Canadian Mineralogist, 1976, № 14, p. 364 - 386.

Kun L., Ruidong Y., Wenyong C., Rui L., Ping T. Trace element and REE geochemistry of the Zhewang gold deposit, southeastern Guizhou Province, China // Chin.J.Geochem, 2014, № 33, p. 109 - 118.

Lambert J.M., Simkovich G., Walker P.L. The kinetics and mechanism of the pyrite-topyrrhotite transformation // Metallurgical and Materials Transactions B, 1998, Vol. 29, Is. 2, p. $951-963$.

Le Vaillant M., Barnes S.J., Fiorentini M.L., Barnes S.-J., Banh A., Miller J. Platinumgroup elements and gold contents of arsenide and sulfarsenide minerals associated with $\mathrm{Ni}$ and Au deposits in Archean greenstone belts // Mineralogical Magazine, 2018, Vol. 82(3), p. $625-647$.

Liang Y., Hoshino K., Thermodynamic calculations of AuxAg1-x - fluid equilibria and their applications for ore-forming conditions // Applied Geochemistry, 2015, № 52, p. 109 - 117.

McDonough W. F. and Sun S.-s. The composition of the Earth // Chemical Geology, 1995, № 120, p. 223 - 253.

Monecke T., Kempe U., Götze J. Genetic significance of the trace element content in metamorphic and hydrothermal quartz: a reconnaissance study // Earth and Planetary Science Letters, 2002, № 202, p. 709 - 724. a

Monecke T., Kempe U., Monecke J., Sals M., Wolf D. Tetrad effect in rare earth element distribution patterns: A method of quantification with application to rock and mineral samples from granite-related rare metal deposits // Geochimica et Cosmochimica Acta, 2002, Vol. 66(7), p. 1185 - 1196. b

Morgan J.W., Wandless G.A. Rare earth element distribution in some hydrothermal elements: Evidence for crystallographic control. // Geochimica et Cosmochimica Acta, 1980, Vol. 44, p. $973-980$.

Naumov E.A., Borisenko A.S., Nevolko P.A., Kovalev K.R., Tessalina S., Sazonov A.M., Savichev A.A., Zvyagina E.A. Gold-sulfide (Au-As) Deposits of the Yenisei Ridge (Russia): Age, Sources of Metals and Nature of Fluids // 13th SGA Biennial Meeting on Mineral Resources in a Sustainable World, 2015, p. 165 - 168.

Pal'yanova G. Physicochemical modeling of the coupled behavior of gold and silver in hydrothermal processes: Gold fineness, $\mathrm{Au} / \mathrm{Ag}$ ratios and their possible implications // Chemical Geology, 2008, № 255, p. 399 - 413.

Rudnick R.L., Gao S. The composition of the continental crust // Treatise on Geochemistry, 2003, Vol. 3, p. $1-64$.

Sazonov A.M., Silyanov S.A., Bayukov O.A., Knyazev Y.V., Zvyagina Y.A., Tishin P.A. Composition and Ligand Microstructure of Arsenopyrite from Gold Ore Deposits of the Yenisei Ridge (Eastern Siberia, Russia) // Minerals, 2019, Vol. 9, 737.

Scott S.D. Chemical behavior of sphalerite and arsenopyrite in hydrothermal and metamorphic environments // Mineralogical Magazine, 1983, Vol. 47, p. 427 - 435.

Taylor S. R. and McClennan S. M. The Continental Crust: Its Composition and Evolution. Blackwell Scientific Publications, Oxford, 1985, 312 p. 
Toulmin P., Barton P.B. A thermodynamic study of pyrite and pyrrhotite // Geochimica et Cosmochimica Acta, 1964, Vol. 288, p. 641 - 671.

Xiaohu H., Hong Z., Weiguang Z., Zhongjie B., Wenjun H. Enrichment of platinumgroup elements (PGE) and Re-Os isotopic tracing for porphyry copper (gold) deposits // Acta Geologica Sinica, 2014, Vol. 88, № 4, p. 1288 - 1309.

Yakubchuk A., Stein H., Wilde A. Results of pilot Re-Os dating of sulfides from the Sukhoi Log and Olympiada orogenic gold deposits, Russia // Ore geology reviews, 2014, № 59, p. $21-28$. 


\section{Подрисуночные подписи}

Рис. 1. a - Географическое положение месторождения; b - Схема геологического строения рудного поля Олимпиадинского месторождения по материалам Олимпиадинской ГРП с упрощениями авторов: (1-7) Рифей. Сухопитская серия: 1 - горбилокская свита $\left(R F_{2} g r\right)$. Переслаивание кварц-хлорит-мусковитовых, двуслюдяных и кварц-мусковитовых с гранатом сланцев и кварцитов; (2-7) кординская свита: 2 - верхняя подсвита $\left(R F_{1} k d_{3}\right)$. Переслаивание высокоглиноземистых гранат-кварц-биотитовых сланцев с силлиманитом, андалузитом и кианитом с кварцитами, кварц-биотитовыми и кварц-мусковитовыми сланцами со ставролитом; (3-5) средняя подсвита: 3 - третья пачка $\left(R F_{1} k d_{2}{ }^{3}\right)$.

Переслаивание сланцев углеродсодержащих двуслюдяных с гранатом, кварц-полевошпатбиотитовых и кварц-полевошпат-биотитовых с гранатом; 4 - вторая пачка $\left(R F_{1} k d_{2}^{2}\right)$. Переслаивание кварц-карбонатно-слюдяных сланцев с мраморизованными известняками; 5 - первая пачка $\left(R F_{1} k d_{2}{ }^{1}\right)$. Переслаивание сланцев биотитовых кварцитовидных, двуслюдяных с гранатом, слюдяных (метаалеврито-глинистых) с кварцитами; (6-7) нижняя подсвита: 6 - вторая пачка $\left(R F_{1} k d_{1}{ }^{2}\right)$. Переслаивание кварцитов, известняков со сланцами (кварц-хлорит-мусковитовыми с гранатом, кварц-хлорит-мусковитовыми, кварцмусковитовыми); 7 - первая пачка $\left(R F_{1} k d_{1}{ }^{1}\right)$. Кварциты, слюдистые кварциты, кварциты слабо известковистые, сланцы биотит-кварцевые и слюдяно-полевошпат-кварцевые. В основании линзы, прослои метапесчанников и реже метагравелитов; (8-9) магматические породы татарско-аяхтинского комплекса: 8 - граниты; 9 - диориты; 10 - геологические границы; 11 - складки: 1 - Иннокентьевская синклиналь, 2 - Медвежинская антиклиналь, 3 - Чиримбинская синклиналь, 4 - Иннокентьевско-Благовещенская антиклиналь; 12 разрывные нарушения; 13 - золоторудные месторождения (а, б, в) и проявления (г): a крупные месторождения: I - Олимпиадинское (Восточное); б - средние месторождения: II - Олимпиадинское (Западное), V - Титимухта; в - мелкие месторождения: III -

Тырадинское, IV - Оленье; г - проявления: VI - Высокое 2, VII - Иннокентьевское, VIII Чиримбинское.

Рис. 2. Спайдер-диаграммы распределения рассеянных элементов в изученных образцах. Значения нормированы на состав верхней коры [Rudnick, Gao, 2003]. Состав пород кординской свиты взят из работы [Лиханов и др., 2006, среднее по двум образцам (E-8 и E-10)]. a - золото и вмещающие породы; b - арсенопирит и вмещающие породы; c пирит (серые), пирротин (синие) и вмещающие породы; $\mathrm{d}$ - стибнит и вмещающие породы.

Рис. 3. Распределения REE в изученных образцах (значения нормированы на хондрит [McDonough, Sun, 1995]. а - золото и породы кординской свиты; b - арсенопирит и породы кординской свиты; с - пирит, пирротин и породы кординской свиты; $d$ - стибнит и породы кординской свиты.

Рис. 4. Распределения REE в изученных образцах (значения нормированы на состав пород кординской свиты ([Лиханов и др., 2006], среднее по двум образцам (Е-8 и E-10). a золото; b - арсенопирит; с - пирит и пирротин; $\mathrm{d}$ - стибнит.

Рис. 5. a-d - нормированные на состав верхней коры [Rudnick, Gao, 2003] содержания благородных металлов в: a - золоте, b - арсенопирите, с - пирите и пирротине, d - стибните; е - фрагмент треугольной диаграммы в координатах Ru-Pt-Pd c фигуративными точками сульфидов и золота месторождения (условные обозначения соответствуют предыдущим рисункам). 
Табл. 1. Основные характеристики изученных образцов

\begin{tabular}{|c|c|c|}
\hline $\begin{array}{l}\text { Полевой (лаб.) } \\
\text { номер }\end{array}$ & $\begin{array}{l}\text { Минерал, } \\
\text { формула }\end{array}$ & Микровключения ${ }^{1}$ \\
\hline $\begin{array}{l}\mathrm{C}-23505 / 305 \\
(45-3)\end{array}$ & $\begin{array}{c}\text { Золото } \\
\mathrm{Au}\end{array}$ & - \\
\hline $\begin{array}{l}\text { С-0175-ИГ-514 } \\
(46-3)\end{array}$ & $\begin{array}{c}\text { Золото } \\
\mathrm{Au}_{0.9} \mathrm{Ag}_{0.1}\end{array}$ & - \\
\hline $503-453(1)$ & $\begin{array}{c}\text { Арсенопирит } \\
{\text { (дипирамидальный })^{2}}^{\mathrm{Fe}_{0.983} \mathrm{As}_{1.004} \mathrm{~S}_{0.996}}\end{array}$ & $\begin{array}{c}\text { Джемсонит, гудмундит, ауростибит, золото, рутил, } \\
\text { мусковит, хлорит, кордиерит(?) }\end{array}$ \\
\hline 503-458.5 (2) & $\begin{array}{c}\text { Арсенопирит } \\
\text { (дипирамидальный) } \\
\mathrm{Fe}_{0.984} \mathrm{As}_{0.977} \mathrm{~S}_{1.023}\end{array}$ & $\begin{array}{l}\text { Пирротин, золото, ауростибит, брейтгауптит, ульманит, } \\
\text { рутил, карбонат, апатит, хлорит, мусковит, Се-монацит }\end{array}$ \\
\hline 503-473.5 (3) & $\begin{array}{c}\text { Арсенопирит } \\
\text { (призматический) } \\
\mathrm{Fe}_{0.978} \mathrm{As}_{1.021} \mathrm{~S}_{0.979}\end{array}$ & $\begin{array}{c}\text { Джемсонит, буланжерит, ауростибит, гудмундит, золото, } \\
\text { карбонат, апатит, кварц, мусковит, хлорит, цоизит, } \\
\text { тремолит-актинолит }\end{array}$ \\
\hline $504-6.5(4)$ & $\begin{array}{c}\text { Арсенопирит } \\
\text { (игольчатый) } \\
\mathrm{Fe}_{0.968} \mathrm{As}_{0.948} \mathrm{~S}_{1.052}\end{array}$ & $\begin{array}{c}\text { Пирит, бертьерит, гудмундит, золото, пирротин, } \\
\text { джемсонит, кварц, мусковит, флюорит }\end{array}$ \\
\hline 506-334.7 (5) & $\begin{array}{c}\text { Арсенопирит } \\
\text { (призматический) } \\
\mathrm{Fe}_{0.982} \mathrm{As}_{0.974} \mathrm{~S}_{1.026}\end{array}$ & $\begin{array}{l}\text { Пирротин, халькопирит, золото, галенит, рутил, апатит, } \\
\text { биотит, мусковит, цоизит, альбит, циркон, Се-монацит }\end{array}$ \\
\hline $511-322(6)$ & $\begin{array}{c}\text { Арсенопирит } \\
\text { (дипирамидальный) } \\
\mathrm{Fe}_{0.980} \mathrm{As}_{1.012} \mathrm{~S}_{0.988}\end{array}$ & $\begin{array}{c}\text { Гудмундит, стибнит, бертьерит, рутил, кварц, апатит, } \\
\text { хлорит, мусковит }\end{array}$ \\
\hline $511-591.4(7)$ & $\begin{array}{c}\text { Арсенопирит } \\
\text { (призматический) } \\
\mathrm{Fe}_{0.975} \mathrm{As}_{1} \mathrm{~S}_{1}\end{array}$ & $\begin{array}{l}\text { Рутил, карбонат, кварц, мусковит, хлорит, циркон, } \\
\text { торианит }\end{array}$ \\
\hline 503-7.4 (8) & $\begin{array}{c}\text { Пирит } \\
\left(\mathrm{Fe}_{0.998} \mathrm{Co}_{0.001} \mathrm{Ni}_{0.001}\right)_{1} \mathrm{~S}_{2}\end{array}$ & $\begin{array}{c}\text { Пирротин, тетраэдрит, джемсонит, халькопирит, } \\
\text { арсенопирит, рутил, апатит, карбонат, мусковит, хлорит, } \\
\text { Се-монацит }\end{array}$ \\
\hline 503-51.8 (9) & $\begin{array}{l}\text { Пирит } \\
\mathrm{Fe}_{1.007} \mathrm{~S}_{2}\end{array}$ & $\begin{array}{c}\text { Гудмундит, джемсонит, арсенопирит, пирротин, } \\
\text { колорадоит, рутил, карбонат, кварц, хлорит, мусковит }\end{array}$ \\
\hline 507-165 (10) & $\begin{array}{c}\text { Пирит } \\
\mathrm{Fe}_{1.003}\left(\mathrm{~S}_{1.999} \mathrm{As}_{0.001}\right)_{2}\end{array}$ & $\begin{array}{c}\text { Галенит, арсенопирит, халькопирит, пирротин, карбонат, } \\
\text { кварц, хлорит, мусковит, ангидрит, цоизит }\end{array}$ \\
\hline 511-483.6 (11) & $\begin{array}{c}\text { Пирит } \\
\left(\mathrm{Fe}_{0.998} \mathrm{Co}_{0.002}\right)_{1}\left(\mathrm{~S}_{1.988} \mathrm{As}_{0.012}\right)_{2}\end{array}$ & $\begin{array}{c}\text { Сурьма самородная, бертьерит, гудмундит, пирротин, } \\
\text { тетраэдрит, кварц, карбонат, хлорит, мусковит }\end{array}$ \\
\hline 511-538.7 (12) & $\begin{array}{c}\text { Пирит } \\
\left(\mathrm{Fe}_{0.994} \mathrm{Co}_{0.004}\right)_{0.998} \mathrm{~S}_{2}\end{array}$ & $\begin{array}{c}\text { Джемсонит, сфалерит, пирротин, галенит, рутил, карбонат, } \\
\text { апатит, кварц, мусковит }\end{array}$ \\
\hline 503-7.4 (13) & $\begin{array}{l}\text { Пирротин } \\
\mathrm{Fe}_{6.969} \mathrm{~S}_{8}\end{array}$ & $\begin{array}{c}\text { Ульманит, арсенопирит, пирит, халькопирит, джемсонит, } \\
\text { бертьерит, гудмундит, рутил, апатит, карбонат, кварц, } \\
\text { хлорит, мусковит }\end{array}$ \\
\hline $505-58(14)$ & $\begin{array}{l}\text { Пирротин } \\
\mathrm{Fe}_{6.993} \mathrm{~S}_{8}\end{array}$ & Рутил, карбонат, кварц, хлорит \\
\hline 506-274.7 (15) & $\begin{array}{l}\text { Пирротин } \\
\mathrm{Fe}_{7.026} \mathrm{~S}_{8}\end{array}$ & $\begin{array}{c}\text { Джемсонит, бертьерит, тетраэдрит, пирит, халькопирит, } \\
\text { брейтгауптит, сурьма самородная, ульманит, карбонат, } \\
\text { биотит }\end{array}$ \\
\hline 511-538.7 (16) & $\begin{array}{l}\text { Пирротин } \\
\mathrm{Fe}_{7.022} \mathrm{~S}_{8}\end{array}$ & $\begin{array}{c}\text { Брейтгауптит, ульманит-виллиамит, рутил, кварц, } \\
\text { карбонат, мусковит }\end{array}$ \\
\hline OC-1 (78) & $\begin{array}{l}\text { Стибнит } \\
\mathrm{Sb}_{2} \mathrm{~S}_{3}\end{array}$ & $\begin{array}{c}\text { Джемсонит, колорадоит, пирит, Ni-арсенопирит, рутил, } \\
\text { карбонат, кварц, хлорит, мусковит }\end{array}$ \\
\hline
\end{tabular}

Примечание:

${ }^{1}$ по данным электронно-микроскопического изучения 20 зерен из каждой пробы (микрозонд Jeol JXA-8100, ИГМ СО РАН, г. Новосибирск, аналитик В.Н. Королюк; СЭМ Tescan Vega III SBH с ЭДС Oxford X-Act, R\&D центр НорНикель ИГДГиГ СФУ, г. Красноярск, аналитик С.А. Сильянов; СЭМ Tescan Vega II LMU с ЭДС OXFORD INCA ENERGY 350, ЦКП «Аналитический центр геохимии природных систем», ТГУ, г. Томск, аналитики Е.В. Корбовяк, К.В. Бестемьянова;

${ }^{2}$ для арсенопирита в скобках указана морфология кристаллов. 
Табл. 2. Содержание рассеянных элементов в изученных образцах, ppm

\begin{tabular}{|c|c|c|c|c|c|c|c|c|c|c|c|c|c|c|c|c|c|c|c|}
\hline \multirow{2}{*}{$\begin{array}{c}\text { Минерал } \\
\text { № лаб. }\end{array}$} & \multicolumn{2}{|c|}{$\mathrm{Au}$} & \multicolumn{7}{|c|}{ Ars } & \multicolumn{5}{|c|}{ Py } & \multicolumn{4}{|c|}{ Pyr } & \multirow{2}{*}{$\begin{array}{c}\text { Stb } \\
78\end{array}$} \\
\hline & $45-3$ & $46-3$ & 1 & 2 & 3 & 4 & 5 & 6 & 7 & 8 & 9 & 10 & 11 & 12 & 13 & 14 & 15 & 16 & \\
\hline $\mathrm{Cu}$ & 211 & 65.78 & 1.59 & $\begin{array}{c}23.2 \\
3\end{array}$ & 4.79 & $\begin{array}{c}35.3 \\
8\end{array}$ & 131 & 3.57 & 5.65 & 210 & 534 & $\begin{array}{c}49.9 \\
9\end{array}$ & 78.02 & 4.42 & $\begin{array}{c}22.7 \\
8\end{array}$ & 378 & $\begin{array}{c}18.4 \\
6\end{array}$ & 365 & $\begin{array}{c}43.1 \\
4\end{array}$ \\
\hline $\mathrm{Pb}$ & 1.49 & 4.06 & 8.86 & 8.65 & 8.01 & $\begin{array}{c}21.5 \\
7\end{array}$ & $\begin{array}{c}32.6 \\
4\end{array}$ & 1.77 & 4.51 & $\begin{array}{c}75.0 \\
7\end{array}$ & 97.62 & $\begin{array}{c}91.7 \\
5\end{array}$ & 51.68 & $\begin{array}{c}42.5 \\
2\end{array}$ & 125 & 5.64 & $\begin{array}{c}58.0 \\
0\end{array}$ & 396 & 139 \\
\hline $\mathrm{Bi}$ & 0.03 & 0.54 & 0.36 & 1.91 & 0.19 & 0.45 & 3.10 & 0.03 & 0.24 & 0.98 & 10.25 & 0.46 & 0.30 & 0.23 & 5.76 & 0.36 & 1.59 & 17.66 & 0.24 \\
\hline $\mathrm{Zn}$ & 11.79 & 29.45 & 3.07 & $\begin{array}{c}20.4 \\
4\end{array}$ & $\begin{array}{c}28.5 \\
1\end{array}$ & 158 & $\begin{array}{c}67.9 \\
8\end{array}$ & 30.99 & $\begin{array}{c}25.7 \\
6\end{array}$ & $\begin{array}{c}41.4 \\
4\end{array}$ & 18.45 & 217 & 16.88 & 1328 & 9.93 & $\begin{array}{c}13.6 \\
9\end{array}$ & 6.48 & 101 & 8.46 \\
\hline $\mathrm{Cr}$ & 3.71 & 3.06 & 1.05 & 3.71 & 2.23 & 2.96 & 7.91 & 1.90 & 8.35 & $\begin{array}{c}12.5 \\
1\end{array}$ & 3.21 & $\begin{array}{c}62.7 \\
7\end{array}$ & 2.88 & 1.08 & 4.02 & 7.46 & 4.33 & 2.45 & 2.37 \\
\hline $\mathrm{Ni}$ & 2.45 & 3.64 & 124 & $\begin{array}{c}54.7 \\
1\end{array}$ & 255 & 124 & 288 & 246 & 542 & 626 & 63.27 & 220 & 61.52 & $\begin{array}{c}42.6 \\
8\end{array}$ & 243 & 494 & 245 & 1148 & 5.98 \\
\hline Co & 0.30 & 0.72 & $\begin{array}{c}22.8 \\
2\end{array}$ & 609 & $\begin{array}{c}62.1 \\
9\end{array}$ & 221 & 1378 & 238 & 1085 & 2356 & 16.44 & 153 & 56.06 & 2635 & $\begin{array}{c}33.5 \\
4\end{array}$ & 108 & 147 & 218 & $\begin{array}{c}14.6 \\
0\end{array}$ \\
\hline $\mathrm{Rb}$ & 0.00 & 0.00 & 0.46 & 0.76 & 2.30 & 1.64 & 2.24 & 0.70 & 1.18 & 4.20 & 1.58 & 11.43 & 1.94 & 1.35 & 0.94 & 0.10 & 0.04 & 0.01 & 0.22 \\
\hline $\mathrm{Sr}$ & 4.54 & 1.73 & 2.49 & 8.52 & $\begin{array}{c}12.0 \\
3\end{array}$ & 8.08 & 5.31 & 10.88 & 6.16 & 9.31 & 3.56 & $\begin{array}{c}43.9 \\
5\end{array}$ & 22.20 & 3.52 & 3.36 & 2.12 & 1.69 & 1.05 & 0.42 \\
\hline W & 6.14 & 0.23 & 1.74 & 5.66 & 5.30 & $\begin{array}{c}29.6 \\
4\end{array}$ & $\begin{array}{c}85.5 \\
8\end{array}$ & $\begin{array}{c}1955 \\
4\end{array}$ & 6.66 & 3.22 & 62.61 & $\begin{array}{c}16.6 \\
6\end{array}$ & 17.22 & 8.08 & 1.24 & $\begin{array}{c}12.6 \\
2\end{array}$ & 3.49 & 0.17 & 0.19 \\
\hline $\mathrm{Ba}$ & 21.90 & 13.35 & 8.64 & 8.90 & $\begin{array}{c}20.6 \\
6\end{array}$ & $\begin{array}{c}23.7 \\
8\end{array}$ & $\begin{array}{c}27.8 \\
5\end{array}$ & 12.76 & $\begin{array}{c}25.4 \\
5\end{array}$ & $\begin{array}{c}68.7 \\
4\end{array}$ & 14.85 & 151 & 23.10 & $\begin{array}{c}21.0 \\
7\end{array}$ & 8.13 & 7.20 & 5.11 & 2.54 & 6.87 \\
\hline $\mathrm{V}$ & 3.17 & 0.72 & 0.46 & 1.52 & 2.04 & 1.74 & 2.27 & 0.59 & 2.06 & 4.58 & 1.21 & 11.33 & 1.39 & 0.74 & 1.29 & 0.39 & 0.48 & 0.13 & 0.19 \\
\hline Sn & 3.35 & 2.25 & 0.82 & 1.55 & 1.86 & 1.60 & 1.76 & 8.18 & 4.31 & 4.22 & 1.69 & $\begin{array}{c}14.9 \\
5\end{array}$ & 1.46 & 0.77 & 2.24 & 0.98 & 0.41 & 1.09 & 1.18 \\
\hline Тa & 0.50 & 0.05 & 0.03 & 0.10 & 0.01 & 0.12 & 0.21 & 0.02 & 0.13 & 0.09 & 0.02 & 0.07 & 0.02 & 0.02 & 0.01 & 0.01 & 0.01 & 0.003 & $\begin{array}{c}0.00 \\
4\end{array}$ \\
\hline $\mathrm{Zr}$ & 9.30 & 0.73 & 11.66 & $\begin{array}{c}25.7 \\
7\end{array}$ & 3.58 & $\begin{array}{c}53.5 \\
9\end{array}$ & $\begin{array}{c}41.7 \\
2\end{array}$ & 5.76 & $\begin{array}{c}53.7 \\
5\end{array}$ & $\begin{array}{c}20.7 \\
8\end{array}$ & 7.71 & $\begin{array}{c}23.2 \\
7\end{array}$ & 4.97 & 4.97 & 6.23 & 0.93 & 0.99 & 0.87 & 0.38 \\
\hline $\mathrm{Nb}$ & 4.66 & 0.11 & 0.41 & 1.35 & 0.14 & 1.53 & 2.81 & 0.30 & 1.81 & 1.19 & 0.37 & 0.66 & 0.20 & 0.24 & 0.19 & 0.11 & 0.08 & 0.06 & 0.01 \\
\hline $\mathrm{Hf}$ & 0.29 & 0.02 & 0.35 & 0.72 & 0.11 & 1.38 & 1.09 & 0.14 & 1.35 & 0.55 & 0.19 & 0.63 & 0.13 & 0.12 & 0.15 & 0.02 & 0.02 & 0.02 & 0.01 \\
\hline Ho & 0.01 & 0.03 & 0.05 & 0.10 & 0.09 & 0.11 & 0.19 & 0.11 & 0.11 & 0.16 & 0.04 & 0.25 & 0.06 & 0.03 & 0.03 & 0.01 & 0.01 & 0.01 & $\begin{array}{c}0.00 \\
3\end{array}$ \\
\hline Th & 0.17 & 0.12 & 0.71 & 1.10 & 0.68 & 0.60 & 2.43 & 0.20 & 2.40 & 0.76 & 0.41 & 1.07 & 0.23 & 0.14 & 0.24 & 0.03 & 0.02 & 0.03 & 0.02 \\
\hline $\mathrm{U}$ & 0.04 & 0.03 & 0.14 & 0.29 & 0.10 & 0.27 & 0.48 & 0.07 & 0.51 & 0.19 & 0.12 & 0.32 & 0.14 & 0.06 & 0.05 & 0.02 & 0.02 & 0.01 & $\begin{array}{c}0.00 \\
5\end{array}$ \\
\hline $\mathrm{Y}$ & 0.21 & 0.64 & 1.19 & 2.89 & 2.59 & 2.89 & 5.34 & 3.45 & 2.99 & 4.28 & 1.12 & 6.41 & 1.61 & 1.00 & 0.93 & 0.26 & 0.18 & 0.16 & 0.11 \\
\hline
\end{tabular}




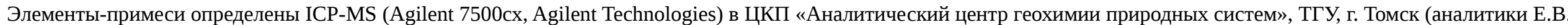
Рабцевич и Е.И. Никитина). 
Tабл. 3. Содержание REE в изученных образцах, ppm

\begin{tabular}{|c|c|c|c|c|c|c|c|c|c|c|c|c|c|c|c|c|c|c|c|}
\hline Минерал & \multicolumn{2}{|c|}{$\mathrm{Au}$} & \multicolumn{7}{|c|}{ Ars } & \multicolumn{5}{|c|}{$\mathrm{Py}$} & \multicolumn{4}{|c|}{ Pyr } & Stb \\
\hline № лаб. & $45-3$ & $46-3$ & 1 & 2 & 3 & 4 & 5 & 6 & 7 & 8 & 9 & 10 & 11 & 12 & 13 & 14 & 15 & 16 & 78 \\
\hline $\mathrm{La}$ & $\begin{array}{c}0.44 \\
5\end{array}$ & $\begin{array}{c}17.98 \\
2\end{array}$ & $\begin{array}{c}2.14 \\
0\end{array}$ & $\begin{array}{c}3.12 \\
4\end{array}$ & $\begin{array}{c}10.49 \\
3\end{array}$ & 2.114 & 5.909 & $\begin{array}{c}1.95 \\
0\end{array}$ & 7.992 & 4.427 & $\begin{array}{c}5.91 \\
8\end{array}$ & 4.663 & $\begin{array}{c}2.00 \\
6\end{array}$ & $\begin{array}{c}0.82 \\
6\end{array}$ & $\begin{array}{c}2.28 \\
1\end{array}$ & $\begin{array}{c}0.18 \\
9\end{array}$ & $\begin{array}{c}0.26 \\
5\end{array}$ & $\begin{array}{c}0.67 \\
5\end{array}$ & $\begin{array}{c}38.81 \\
7\end{array}$ \\
\hline $\mathrm{Ce}$ & $\begin{array}{c}0.75 \\
8\end{array}$ & $\begin{array}{c}28.38 \\
2\end{array}$ & $\begin{array}{c}3.65 \\
8\end{array}$ & $\begin{array}{c}4.85 \\
6\end{array}$ & 9.981 & $\begin{array}{c}4.15 \\
7\end{array}$ & 11.739 & $\begin{array}{c}2.30 \\
8\end{array}$ & $\begin{array}{c}16.31 \\
4\end{array}$ & $\begin{array}{c}10.02 \\
1\end{array}$ & $\begin{array}{c}2.15 \\
1\end{array}$ & $\begin{array}{c}10.60 \\
0\end{array}$ & $\begin{array}{c}3.10 \\
0\end{array}$ & $\begin{array}{c}1.83 \\
0\end{array}$ & $\begin{array}{c}4.69 \\
8\end{array}$ & $\begin{array}{c}0.39 \\
9\end{array}$ & $\begin{array}{c}0.40 \\
8\end{array}$ & $\begin{array}{c}0.62 \\
7\end{array}$ & 1.775 \\
\hline $\operatorname{Pr}$ & $\begin{array}{c}0.06 \\
0\end{array}$ & 3.335 & $\begin{array}{c}0.40 \\
9\end{array}$ & $\begin{array}{c}0.58 \\
3\end{array}$ & 2.139 & $\begin{array}{c}0.35 \\
8\end{array}$ & 1.057 & $\begin{array}{c}0.37 \\
8\end{array}$ & 1.652 & 0.957 & $\begin{array}{c}0.20 \\
9\end{array}$ & 1.068 & $\begin{array}{c}0.29 \\
7\end{array}$ & $\begin{array}{c}0.17 \\
9\end{array}$ & $\begin{array}{c}0.44 \\
8\end{array}$ & $\begin{array}{c}0.03 \\
5\end{array}$ & $\begin{array}{c}0.03 \\
8\end{array}$ & $\begin{array}{c}0.05 \\
2\end{array}$ & 0.085 \\
\hline $\mathrm{Nd}$ & $\begin{array}{c}0.19 \\
6\end{array}$ & 11.388 & $\begin{array}{c}1.43 \\
5\end{array}$ & $\begin{array}{c}2.02 \\
9\end{array}$ & 8.329 & $\begin{array}{c}1.23 \\
3\end{array}$ & 3.695 & $\begin{array}{c}1.53 \\
3\end{array}$ & 6.399 & 3.639 & $\begin{array}{c}0.76 \\
0\end{array}$ & 4.191 & $\begin{array}{c}1.16 \\
1\end{array}$ & $\begin{array}{c}0.69 \\
6\end{array}$ & $\begin{array}{c}1.66 \\
3\end{array}$ & $\begin{array}{c}0.13 \\
8\end{array}$ & $\begin{array}{c}0.15 \\
4\end{array}$ & $\begin{array}{c}0.19 \\
7\end{array}$ & 0.067 \\
\hline $\mathrm{Sm}$ & $\begin{array}{c}0.03 \\
7\end{array}$ & 2.173 & $\begin{array}{c}0.26 \\
9\end{array}$ & $\begin{array}{c}0.40 \\
6\end{array}$ & 1.391 & $\begin{array}{c}0.23 \\
2\end{array}$ & 0.610 & $\begin{array}{c}0.38 \\
0\end{array}$ & 1.257 & 0.704 & $\begin{array}{c}0.15 \\
7\end{array}$ & 0.961 & $\begin{array}{c}0.26 \\
0\end{array}$ & $\begin{array}{c}0.14 \\
6\end{array}$ & $\begin{array}{c}0.29 \\
6\end{array}$ & $\begin{array}{c}0.03 \\
7\end{array}$ & $\begin{array}{c}0.02 \\
9\end{array}$ & $\begin{array}{c}0.03 \\
4\end{array}$ & 0.015 \\
\hline Eu & $\begin{array}{c}0.01 \\
0\end{array}$ & 0.450 & $\begin{array}{c}0.05 \\
6\end{array}$ & $\begin{array}{c}0.10 \\
5\end{array}$ & 0.151 & $\begin{array}{c}0.05 \\
4\end{array}$ & 0.112 & $\begin{array}{c}0.06 \\
4\end{array}$ & 0.183 & 0.120 & $\begin{array}{c}0.02 \\
9\end{array}$ & 0.216 & $\begin{array}{c}0.05 \\
5\end{array}$ & $\begin{array}{c}0.02 \\
2\end{array}$ & $\begin{array}{c}0.05 \\
3\end{array}$ & $\begin{array}{c}0.02 \\
1\end{array}$ & $\begin{array}{c}0.00 \\
7\end{array}$ & $\begin{array}{c}0.00 \\
6\end{array}$ & 0.005 \\
\hline Gd & $\begin{array}{c}0.03 \\
5\end{array}$ & 1.304 & $\begin{array}{c}0.23 \\
3\end{array}$ & $\begin{array}{c}0.43 \\
0\end{array}$ & 1.128 & $\begin{array}{c}0.25 \\
1\end{array}$ & 0.598 & $\begin{array}{c}0.45 \\
6\end{array}$ & 0.998 & 0.710 & 0.211 & 0.987 & $\begin{array}{c}0.26 \\
4\end{array}$ & $\begin{array}{c}0.14 \\
6\end{array}$ & $\begin{array}{c}0.24 \\
3\end{array}$ & $\begin{array}{c}0.03 \\
9\end{array}$ & $\begin{array}{c}0.03 \\
1\end{array}$ & $\begin{array}{c}0.03 \\
4\end{array}$ & 0.062 \\
\hline $\mathrm{Tb}$ & $\begin{array}{c}0.00 \\
6\end{array}$ & 0.108 & $\begin{array}{c}0.03 \\
9\end{array}$ & $\begin{array}{c}0.06 \\
9\end{array}$ & 0.137 & $\begin{array}{c}0.05 \\
1\end{array}$ & 0.108 & $\begin{array}{c}0.08 \\
0\end{array}$ & 0.126 & 0.117 & $\begin{array}{c}0.03 \\
0\end{array}$ & 0.171 & $\begin{array}{c}0.04 \\
3\end{array}$ & $\begin{array}{c}0.02 \\
5\end{array}$ & $\begin{array}{c}0.03 \\
2\end{array}$ & $\begin{array}{c}0.00 \\
7\end{array}$ & $\begin{array}{c}0.00 \\
6\end{array}$ & $\begin{array}{c}0.00 \\
5\end{array}$ & 0.016 \\
\hline Dy & $\begin{array}{c}0.04 \\
0\end{array}$ & 0.350 & $\begin{array}{c}0.24 \\
5\end{array}$ & $\begin{array}{c}0.46 \\
5\end{array}$ & 0.616 & $\begin{array}{c}0.40 \\
5\end{array}$ & 0.778 & $\begin{array}{c}0.54 \\
8\end{array}$ & 0.594 & 0.757 & 0.211 & 1.081 & $\begin{array}{c}0.27 \\
6\end{array}$ & $\begin{array}{c}0.15 \\
8\end{array}$ & $\begin{array}{c}0.16 \\
6\end{array}$ & $\begin{array}{c}0.04 \\
8\end{array}$ & $\begin{array}{c}0.03 \\
2\end{array}$ & $\begin{array}{c}0.03 \\
0\end{array}$ & 0.275 \\
\hline Ho & $\begin{array}{c}0.00 \\
8\end{array}$ & 0.028 & $\begin{array}{c}0.04 \\
9\end{array}$ & $\begin{array}{c}0.10 \\
2\end{array}$ & 0.094 & 0.111 & 0.192 & 0.114 & 0.114 & 0.156 & $\begin{array}{c}0.04 \\
0\end{array}$ & 0.252 & $\begin{array}{c}0.06 \\
0\end{array}$ & $\begin{array}{c}0.03 \\
5\end{array}$ & $\begin{array}{c}0.03 \\
5\end{array}$ & 0.011 & $\begin{array}{c}0.00 \\
7\end{array}$ & $\begin{array}{c}0.00 \\
6\end{array}$ & 0.003 \\
\hline Er & $\begin{array}{c}0.02 \\
2\end{array}$ & 0.050 & $\begin{array}{c}0.13 \\
1\end{array}$ & $\begin{array}{c}0.33 \\
7\end{array}$ & 0.205 & $\begin{array}{c}0.31 \\
7\end{array}$ & 0.577 & $\begin{array}{c}0.31 \\
8\end{array}$ & 0.332 & 0.467 & 0.117 & 0.730 & $\begin{array}{c}0.17 \\
3\end{array}$ & $\begin{array}{c}0.10 \\
1\end{array}$ & $\begin{array}{c}0.09 \\
8\end{array}$ & $\begin{array}{c}0.03 \\
0\end{array}$ & $\begin{array}{c}0.01 \\
8\end{array}$ & $\begin{array}{c}0.01 \\
6\end{array}$ & 0.012 \\
\hline $\mathrm{Tm}$ & $\begin{array}{c}0.00 \\
3\end{array}$ & 0.006 & $\begin{array}{c}0.02 \\
0\end{array}$ & $\begin{array}{c}0.06 \\
1\end{array}$ & 0.025 & $\begin{array}{c}0.05 \\
4\end{array}$ & 0.100 & $\begin{array}{c}0.04 \\
3\end{array}$ & 0.055 & 0.075 & $\begin{array}{c}0.01 \\
8\end{array}$ & 0.118 & $\begin{array}{c}0.02 \\
7\end{array}$ & $\begin{array}{c}0.01 \\
7\end{array}$ & $\begin{array}{c}0.01 \\
5\end{array}$ & $\begin{array}{c}0.00 \\
4\end{array}$ & $\begin{array}{c}0.00 \\
3\end{array}$ & $\begin{array}{c}0.00 \\
2\end{array}$ & 0.002 \\
\hline $\mathrm{Yb}$ & $\begin{array}{c}0.01 \\
8\end{array}$ & 0.033 & $\begin{array}{c}0.13 \\
5\end{array}$ & $\begin{array}{c}0.44 \\
2\end{array}$ & 0.125 & $\begin{array}{c}0.33 \\
7\end{array}$ & 0.646 & $\begin{array}{c}0.23 \\
2\end{array}$ & 0.361 & 0.455 & 0.114 & 0.765 & $\begin{array}{c}0.18 \\
3\end{array}$ & $\begin{array}{c}0.10 \\
7\end{array}$ & $\begin{array}{c}0.09 \\
0\end{array}$ & $\begin{array}{c}0.03 \\
0\end{array}$ & $\begin{array}{c}0.01 \\
5\end{array}$ & $\begin{array}{c}0.01 \\
6\end{array}$ & 0.011 \\
\hline $\mathrm{Lu}$ & $\begin{array}{c}0.00 \\
3\end{array}$ & 0.005 & $\begin{array}{c}0.02 \\
1\end{array}$ & $\begin{array}{c}0.08 \\
2\end{array}$ & 0.016 & $\begin{array}{c}0.05 \\
1\end{array}$ & 0.101 & $\begin{array}{c}0.03 \\
1\end{array}$ & 0.058 & 0.073 & $\begin{array}{c}0.01 \\
8\end{array}$ & 0.125 & $\begin{array}{c}0.02 \\
8\end{array}$ & $\begin{array}{c}0.01 \\
7\end{array}$ & $\begin{array}{c}0.01 \\
2\end{array}$ & $\begin{array}{c}0.00 \\
4\end{array}$ & $\begin{array}{c}0.00 \\
3\end{array}$ & $\begin{array}{c}0.00 \\
2\end{array}$ & 0.003 \\
\hline$\sum \mathrm{REE}$ & 1.64 & 65.59 & 8.84 & $\begin{array}{c}13.0 \\
9\end{array}$ & 34.83 & 9.73 & 26.22 & 8.44 & 36.44 & 22.68 & 9.98 & 25.93 & 7.93 & 4.31 & $\begin{array}{c}10.1 \\
3 \\
\end{array}$ & 0.99 & 1.01 & 1.70 & 41.15 \\
\hline
\end{tabular}

$\mathrm{Au}$ - золото, Ars - арсенопирит, Рy - пирит, Pyr - пирротин, Stb - стибнит.

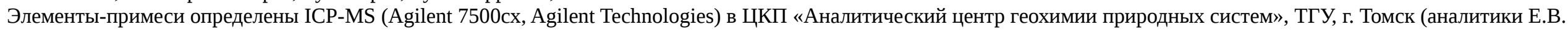
Рабцевич и Е.И. Никитина). 
Табл. 4. Индикаторные отношения для изученных образцов

\begin{tabular}{|c|c|c|c|c|c|c|c|c|c|c|c|c|c|c|c|c|c|c|c|}
\hline Минерал ${ }^{1}$ & \multicolumn{2}{|c|}{$\mathrm{Au}$} & \multicolumn{7}{|c|}{ Ars } & \multicolumn{5}{|c|}{ Py } & \multicolumn{4}{|c|}{ Pyr } & Stb \\
\hline № лаб. & $45-3$ & $46-3$ & 1 & 2 & 3 & 4 & 5 & 6 & 7 & 8 & 9 & 10 & 11 & 12 & 13 & 14 & 15 & 16 & 78 \\
\hline$\sum \mathrm{REE}$ & 1.64 & 65.59 & 8.84 & $\begin{array}{c}13.0 \\
9\end{array}$ & $\begin{array}{c}34.8 \\
3\end{array}$ & 9.73 & $\begin{array}{c}26.2 \\
2\end{array}$ & 8.44 & $\begin{array}{c}36.4 \\
4\end{array}$ & $\begin{array}{c}22.6 \\
8\end{array}$ & 9.98 & $\begin{array}{c}25.9 \\
3\end{array}$ & 7.93 & 4.31 & $\begin{array}{c}10.1 \\
3\end{array}$ & 0.99 & 1.01 & 1.70 & 41.15 \\
\hline$\sum$ LREE & 1.46 & 61.09 & 7.64 & $\begin{array}{c}10.5 \\
9\end{array}$ & $\begin{array}{c}30.9 \\
4\end{array}$ & 7.86 & $\begin{array}{c}22.4 \\
0\end{array}$ & 6.17 & $\begin{array}{c}32.3 \\
6\end{array}$ & $\begin{array}{c}19.0 \\
4\end{array}$ & 9.04 & $\begin{array}{c}20.5 \\
2\end{array}$ & 6.56 & 3.53 & 9.09 & 0.76 & 0.87 & 1.55 & 40.74 \\
\hline$\sum$ MREE & 0.05 & 2.62 & 0.33 & 0.51 & 1.54 & 0.29 & 0.72 & 0.44 & 1.44 & 0.82 & 0.19 & 1.18 & 0.31 & 0.17 & 0.35 & 0.06 & 0.04 & 0.04 & 0.02 \\
\hline$\sum$ HREE & 0.14 & 1.88 & 0.87 & 1.99 & 2.35 & 1.58 & 3.10 & 1.82 & 2.64 & 2.81 & 0.76 & 4.23 & 1.05 & 0.61 & 0.69 & 0.17 & 0.11 & 0.11 & 0.39 \\
\hline$\sum \mathrm{L} / \sum \mathrm{H}$ & $\begin{array}{c}10.7 \\
2\end{array}$ & 32.46 & 8.76 & 5.33 & $\begin{array}{c}13.1 \\
9\end{array}$ & 4.98 & 7.23 & 3.38 & $\begin{array}{c}12.2 \\
6\end{array}$ & 6.78 & 11.93 & 4.85 & 6.24 & 5.81 & $\begin{array}{c}13.1 \\
8\end{array}$ & 4.43 & 7.61 & $\begin{array}{c}13.8 \\
9\end{array}$ & 105.75 \\
\hline $\mathrm{Eu} / \mathrm{Eu}^{* 2}$ & 0.82 & 0.82 & 0.68 & 0.77 & 0.37 & 0.68 & 0.56 & 0.47 & 0.50 & 0.52 & 0.49 & 0.68 & 0.64 & 0.46 & 0.61 & 1.70 & 0.68 & 0.50 & 0.48 \\
\hline $\mathrm{Ce} / \mathrm{Ce}^{*^{2}}$ & 1.12 & 0.89 & 0.95 & 0.87 & 0.51 & 1.16 & 1.14 & 0.65 & 1.09 & 1.18 & 0.47 & 1.15 & 0.97 & 1.15 & 1.12 & 1.18 & 0.98 & 0.81 & 0.24 \\
\hline $\mathrm{Tm} / \mathrm{Tm}^{* 2}$ & 1.08 & 0.89 & 0.96 & 1.03 & 1.00 & 1.08 & 1.07 & 1.02 & 1.04 & 1.06 & 1.01 & 1.03 & 0.98 & 1.07 & 1.03 & 0.94 & 1.04 & 0.89 & 1.32 \\
\hline $\mathrm{TE3}^{3}$ & 0.04 & 0.15 & 0.01 & 0.06 & 0.02 & 0.05 & 0.06 & 0.02 & 0.11 & 0.02 & 0.09 & 0.05 & 0.04 & 0.03 & 0.12 & 0.05 & 0.08 & 0.02 & 7.09 \\
\hline $\mathrm{TE}^{3}$ & 0.05 & 0.12 & 0.03 & 0.03 & 0.05 & 0.07 & 0.06 & 0.02 & 0.03 & 0.04 & 0.03 & 0.02 & 0.01 & 0.04 & 0.08 & 0.07 & 0.08 & 0.07 & 0.24 \\
\hline $\mathrm{La}_{\mathrm{n}} / \mathrm{Yb}_{\mathrm{n}}{ }^{4}$ & $\begin{array}{c}16.6 \\
7\end{array}$ & $\begin{array}{c}371.9 \\
1\end{array}$ & $\begin{array}{c}10.7 \\
9\end{array}$ & 4.80 & $\begin{array}{c}57.0 \\
9\end{array}$ & 4.26 & 6.21 & 5.70 & $\begin{array}{c}15.0 \\
3\end{array}$ & 6.61 & $\begin{array}{c}35.4 \\
1\end{array}$ & 4.14 & 7.44 & 5.22 & $\begin{array}{c}17.2 \\
3\end{array}$ & 4.35 & 11.76 & $\begin{array}{c}28.6 \\
6\end{array}$ & $\begin{array}{c}2320.2 \\
4\end{array}$ \\
\hline $\mathrm{La}_{\mathrm{n}} / \mathrm{Sm}_{\mathrm{n}}{ }^{4}$ & 7.50 & 5.17 & 4.96 & 4.80 & 4.71 & 5.69 & 6.05 & 3.20 & 3.97 & 3.93 & $\begin{array}{c}23.5 \\
9\end{array}$ & 3.03 & 4.82 & 3.53 & 4.81 & 3.20 & 5.67 & $\begin{array}{c}12.3 \\
9\end{array}$ & $\begin{array}{c}1661.2 \\
0\end{array}$ \\
\hline $\mathrm{Gd}_{\mathrm{n}} / \mathrm{Yb}_{\mathrm{n}}{ }^{4}$ & 1.58 & 32.11 & 1.40 & 0.79 & 7.31 & 0.60 & 0.75 & 1.59 & 2.23 & 1.26 & 1.50 & 1.04 & 1.17 & 1.10 & 2.19 & 1.06 & 1.63 & 1.74 & 4.41 \\
\hline $\mathrm{La}_{\mathrm{n}} / \mathrm{Yb}_{\mathrm{n}}{ }^{5}$ & 1.30 & 28.96 & 0.84 & 0.37 & 4.45 & 0.33 & 0.48 & 0.44 & 1.17 & 0.51 & 2.76 & 0.32 & 0.58 & 0.41 & 1.34 & 0.34 & 0.92 & 2.23 & 180.69 \\
\hline $\mathrm{La}_{\mathrm{n}} / \mathrm{Sm}_{\mathrm{n}}{ }^{5}$ & 1.78 & 1.23 & 1.18 & 1.14 & 1.12 & 1.35 & 1.44 & 0.76 & 0.94 & 0.93 & 5.61 & 0.72 & 1.15 & 0.84 & 1.14 & 0.76 & 1.35 & 2.94 & 394.73 \\
\hline $\mathrm{Gd}_{\mathrm{n}} / \mathrm{Yb}_{\mathrm{n}}{ }^{5}$ & 0.85 & 17.22 & 0.75 & 0.42 & 3.92 & 0.32 & 0.40 & 0.85 & 1.20 & 0.68 & 0.80 & 0.56 & 0.62 & 0.59 & 1.17 & 0.57 & 0.87 & 0.93 & 2.37 \\
\hline Y/Dy & 5.22 & 1.82 & 4.86 & 6.22 & 4.21 & 7.14 & 6.86 & 6.30 & 5.03 & 5.65 & 5.29 & 5.92 & 5.83 & 6.34 & 5.58 & 5.46 & 5.63 & 5.43 & 0.38 \\
\hline $\mathrm{Y} / \mathrm{Er}$ & 9.67 & 12.75 & 9.04 & 8.59 & $\begin{array}{c}12.6 \\
4\end{array}$ & 9.13 & 9.24 & $\begin{array}{c}10.8 \\
5\end{array}$ & 9.01 & 9.16 & 9.59 & 8.78 & 9.30 & 9.89 & 9.48 & 8.83 & 9.84 & $\begin{array}{c}10.1 \\
2\end{array}$ & 8.86 \\
\hline $\mathrm{Th} / \mathrm{U}$ & 4.44 & 4.26 & 4.94 & 3.80 & 6.59 & 2.27 & 5.10 & 3.05 & 4.71 & 4.01 & 3.30 & 3.37 & 1.70 & 2.45 & 4.79 & 1.78 & 1.32 & 2.13 & 4.27 \\
\hline $\mathrm{Co} / \mathrm{Ni}$ & 0.12 & 0.20 & 0.18 & 11.13 & 0.24 & 1.78 & 4.79 & 0.97 & 2.00 & 3.76 & 0.26 & 0.69 & 0.91 & 61.7 & 0.14 & 0.22 & 0.60 & 0.19 & 0.41 \\
\hline $\mathrm{Hf} / \mathrm{Sm}$ & 7.92 & 0.01 & 1.31 & 1.77 & 0.08 & 5.94 & 1.79 & 0.38 & 1.07 & 0.78 & 1.21 & 0.66 & 0.50 & 0.84 & 0.49 & 0.56 & 0.77 & 0.63 & 0.82 \\
\hline $\mathrm{Nb} / \mathrm{La}$ & $\begin{array}{c}10.4 \\
6\end{array}$ & 0.01 & 0.19 & 0.43 & 0.01 & 0.72 & 0.48 & 0.16 & 0.23 & 0.27 & 0.06 & 0.14 & 0.10 & 0.29 & 0.08 & 0.56 & 0.32 & 0.08 & 0.0003 \\
\hline $\mathrm{Th} / \mathrm{La}$ & 0.39 & 0.01 & 0.33 & 0.35 & 0.06 & 0.29 & 0.41 & 0.10 & 0.30 & 0.17 & 0.07 & 0.23 & 0.12 & 0.17 & 0.11 & 0.17 & 0.08 & 0.05 & 0.001 \\
\hline $\mathrm{Sm} / \mathrm{Nd}$ & 0.19 & 0.19 & 0.19 & 0.20 & 0.17 & 0.19 & 0.17 & 0.25 & 0.20 & 0.19 & 0.21 & 0.23 & 0.22 & 0.21 & 0.18 & 0.27 & 0.19 & 0.17 & 0.22 \\
\hline
\end{tabular}
Примечания:

${ }^{1} \mathrm{Au}$ - золото, Ars - арсенопирит, Ру - пирит, Pyr - пирротин, Stb - стибнит;

${ }^{2} \mathrm{Ce}$ и Eu аномалии рассчитаны по формулам: Ce/Ce*=Ce ${ }_{n} / \sqrt{ }\left(\mathrm{La}_{n} * \mathrm{Pr}_{\mathrm{n}}\right)$ и Eu/Eu*=Eun $/ \sqrt{ }\left(\mathrm{Sm}_{\mathrm{n}} * \mathrm{Gd}_{\mathrm{n}}\right)$, [Monecke et al., 2002, a]. Аномалия тулия рассчитана аналогично:

$\mathrm{Tm} / \mathrm{Tm}^{*}=\mathrm{Tm}_{\mathrm{n}} / \sqrt{ }\left(\mathrm{Er}_{\mathrm{n}} * \mathrm{Yb}_{\mathrm{n}}\right)$;

${ }^{3}$ Расчет тэтрадного эффекта фракционирования REE (TE3, TE4) произведен по формулам, взятым из работы [Monecke et al., 2002, b]; 
${ }^{4}$ Отношение значений, нормированных на хондрит [McDonough, Sun, 1995];

${ }^{5}$ Отношение значений, нормированных на состав вмещающих пород кординской свиты ([Лиханов и др., 2006], среднее по двум образцам (Е-8 и Е-10).

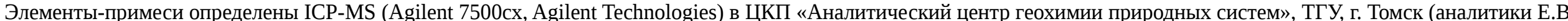

Рабцевич и Е.И. Никитина). 
Табл. 5. Содержание благородных металлов в исследованных образцах, ppm

\begin{tabular}{c|c|c|c|c|c|c|c|c}
\hline Минерал $^{1}$ & № лаб. & $\mathrm{Ru}$ & $\mathrm{Pd}$ & $\mathrm{Pt}$ & $\mathrm{Au}$ & $\mathrm{Ag}$ & $\begin{array}{c}\mathrm{Au} / \mathrm{A} \\
\mathrm{g}\end{array}$ & $\begin{array}{c}\mathrm{Pt} / \mathrm{P} \\
\mathrm{d}\end{array}$ \\
\hline \multirow{3}{*}{$\mathrm{Au}$} & $45-3$ & 0.002 & 0.070 & 0.012 & $\begin{array}{c}100.00 \\
2\end{array}$ & $0.00^{2}$ & - & 0.17 \\
& $46-3$ & 0.002 & 0.196 & 0.058 & $89.98^{2}$ & $10.02^{2}$ & 8.98 & 0.29 \\
\hline \multirow{4}{*}{ Ars } & 1 & 0.001 & 0.028 & 0.006 & 1.943 & 0.113 & 17.24 & 0.19 \\
& 2 & 0.001 & 0.090 & 0.011 & 0.878 & 3.206 & 0.27 & 0.12 \\
& 3 & 0.001 & 0.066 & 0.004 & 0.361 & 2.175 & 0.17 & 0.06 \\
& 4 & 0.001 & 0.082 & 0.019 & 93.668 & 1.127 & 83.10 & 0.24 \\
& 5 & 0.002 & 0.139 & 0.023 & 12.518 & 1.049 & 11.94 & 0.16 \\
& 7 & 0.002 & 0.094 & 0.003 & 4.128 & 6.348 & 0.65 & 0.03 \\
& 7 & 0.001 & 0.089 & 0.020 & 2.219 & 0.546 & 4.07 & 0.22 \\
\hline \multirow{5}{*}{ Py } & 9 & 0.001 & 0.126 & 0.010 & 0.154 & 3.465 & 0.04 & 0.08 \\
& 10 & 0.001 & 0.042 & 0.002 & 2.100 & 1.312 & 1.60 & 0.05 \\
& 11 & 0.008 & 0.161 & 0.105 & 0.545 & 4.021 & 0.14 & 0.65 \\
& 12 & 0.000 & 0.051 & 0.002 & 2.161 & 22.878 & 0.09 & 0.03 \\
& 13 & 0.001 & 0.022 & 0.004 & 0.175 & 23.323 & 0.01 & 0.17 \\
Pyr & 14 & 0.002 & 0.023 & 0.010 & 0.193 & 0.338 & 0.57 & 0.41 \\
& 15 & 0.001 & 0.009 & 0.003 & 0.100 & 0.183 & 0.55 & 0.31 \\
& 16 & 0.001 & 0.024 & 0.002 & 0.315 & 3.848 & 0.08 & 0.08 \\
\hline Stb & 78 & 0.001 & 0.007 & 0.009 & 6.435 & 1.734 & 3.71 & 1.28 \\
\hline
\end{tabular}

Примечание:

${ }^{1} \mathrm{Au}$ - золото, Ars - арсенопирит, Ру - пирит, Pyr - пирротин, Stb - стибнит;

${ }^{2}$ в мас.\% по данным микрорентгеноспектрального анализа: СЭМ Tescan Vega III SBH с ЭДС Oxford X-Act, анализ выполнен в R\&D центре НорНикель ИГДГиГ СФУ, г. Красноярск (аналитик С.А. Сильянов); остальные анализы выполнены методом ICP-MS (Agilent 7500cx, Agilent Technologies) в ЦКП

«Аналитический центр геохимии природных систем», ТГУ, г. Томск (аналитики Е.В. Рабцевич и Е.И. Никитина). 

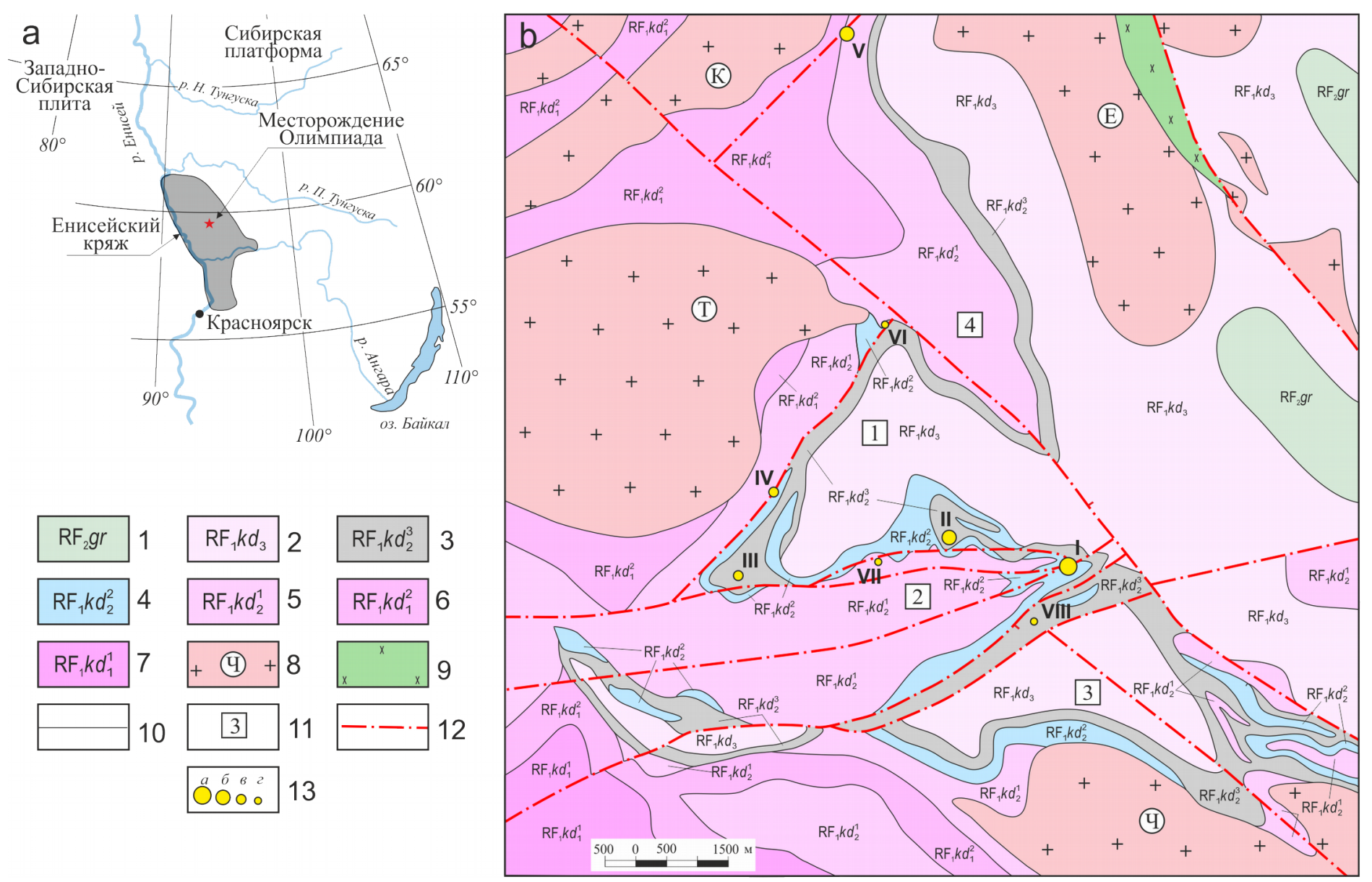

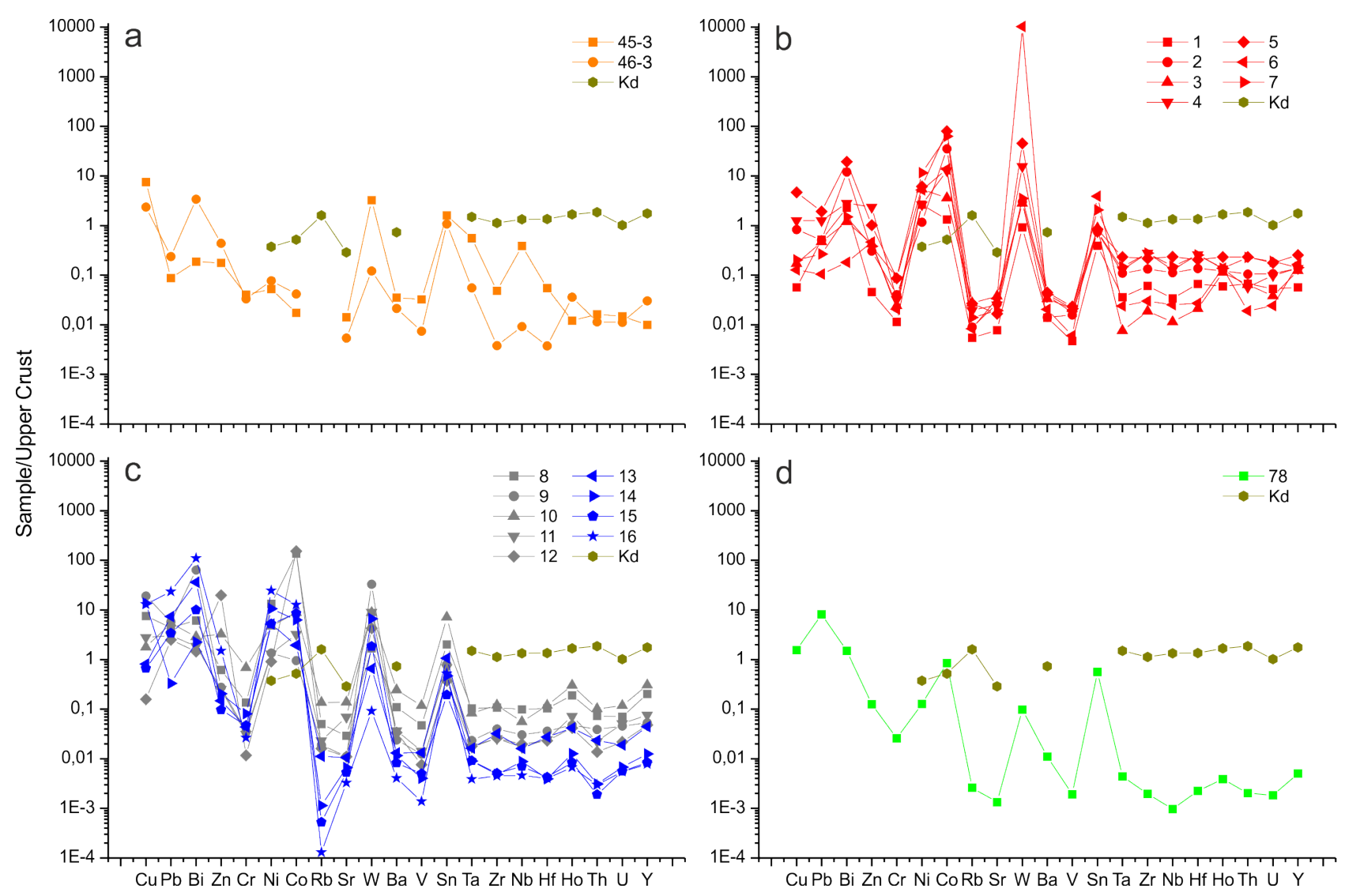

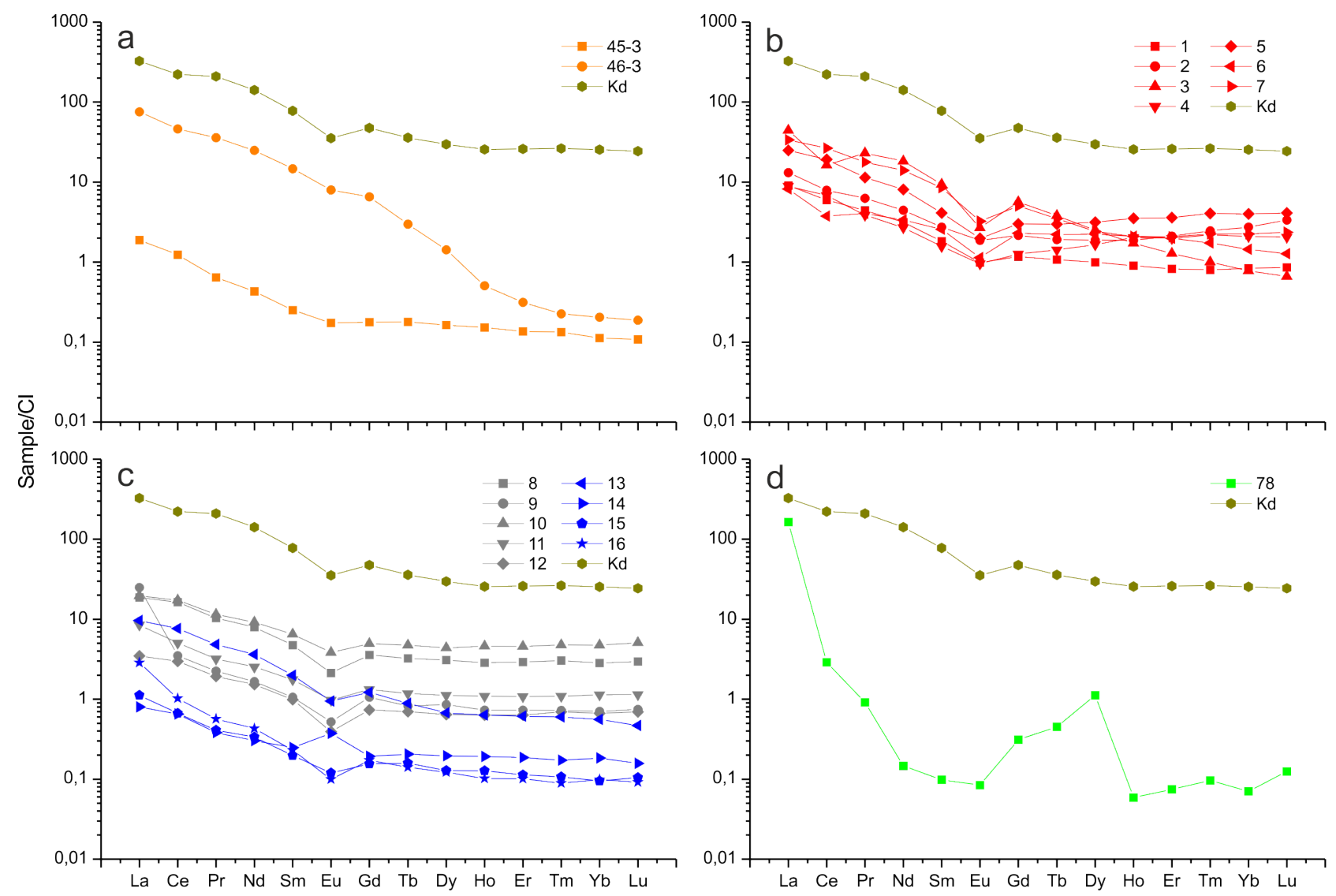

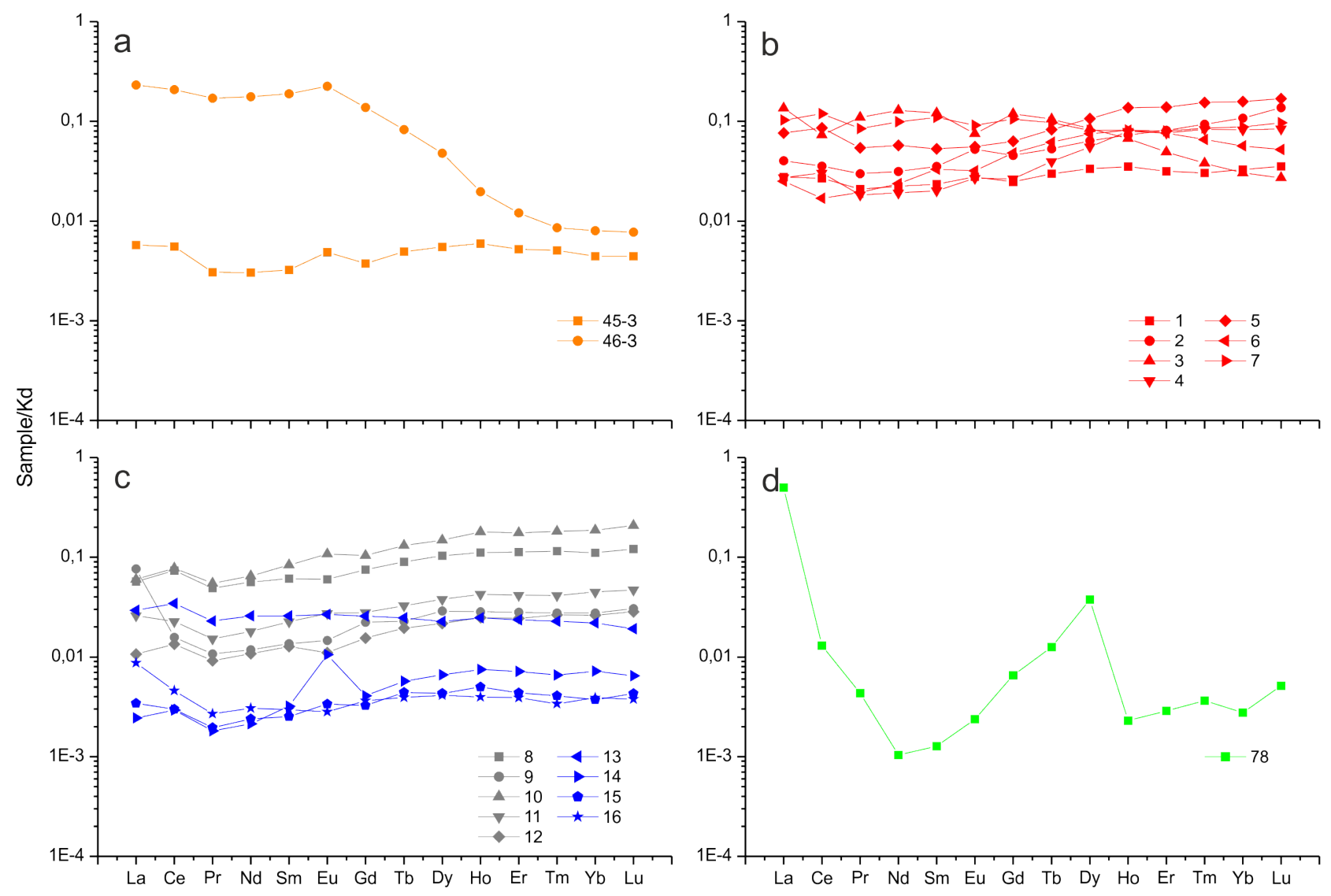

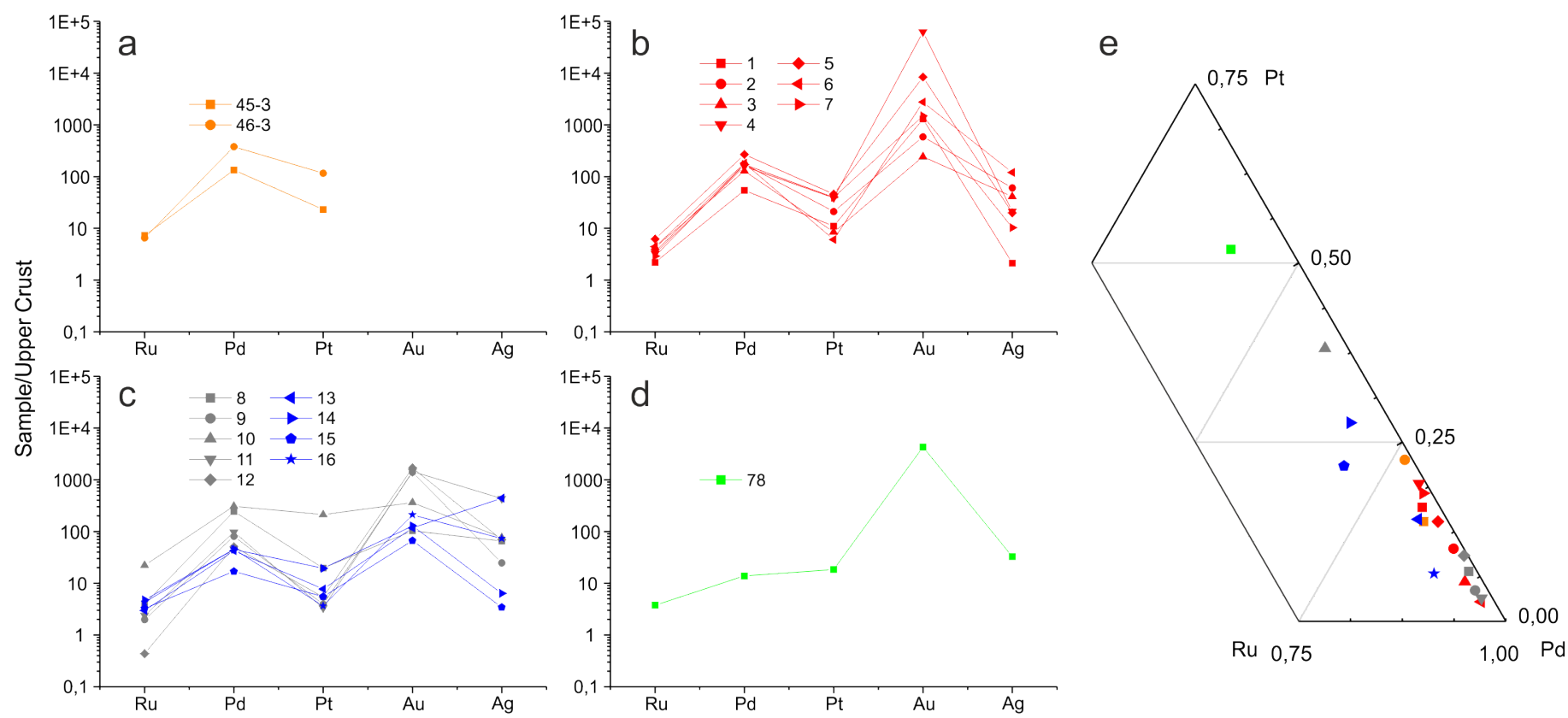

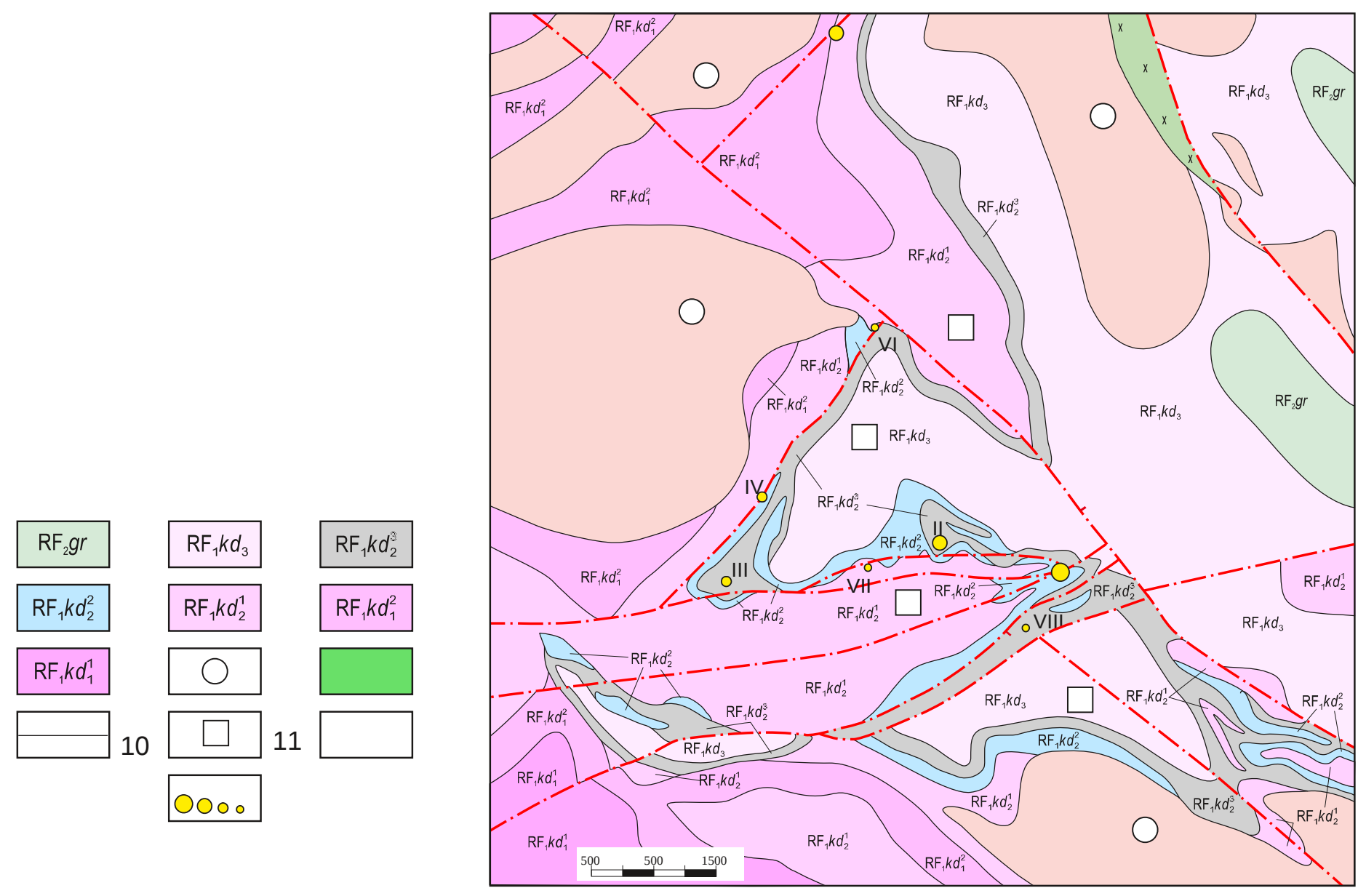


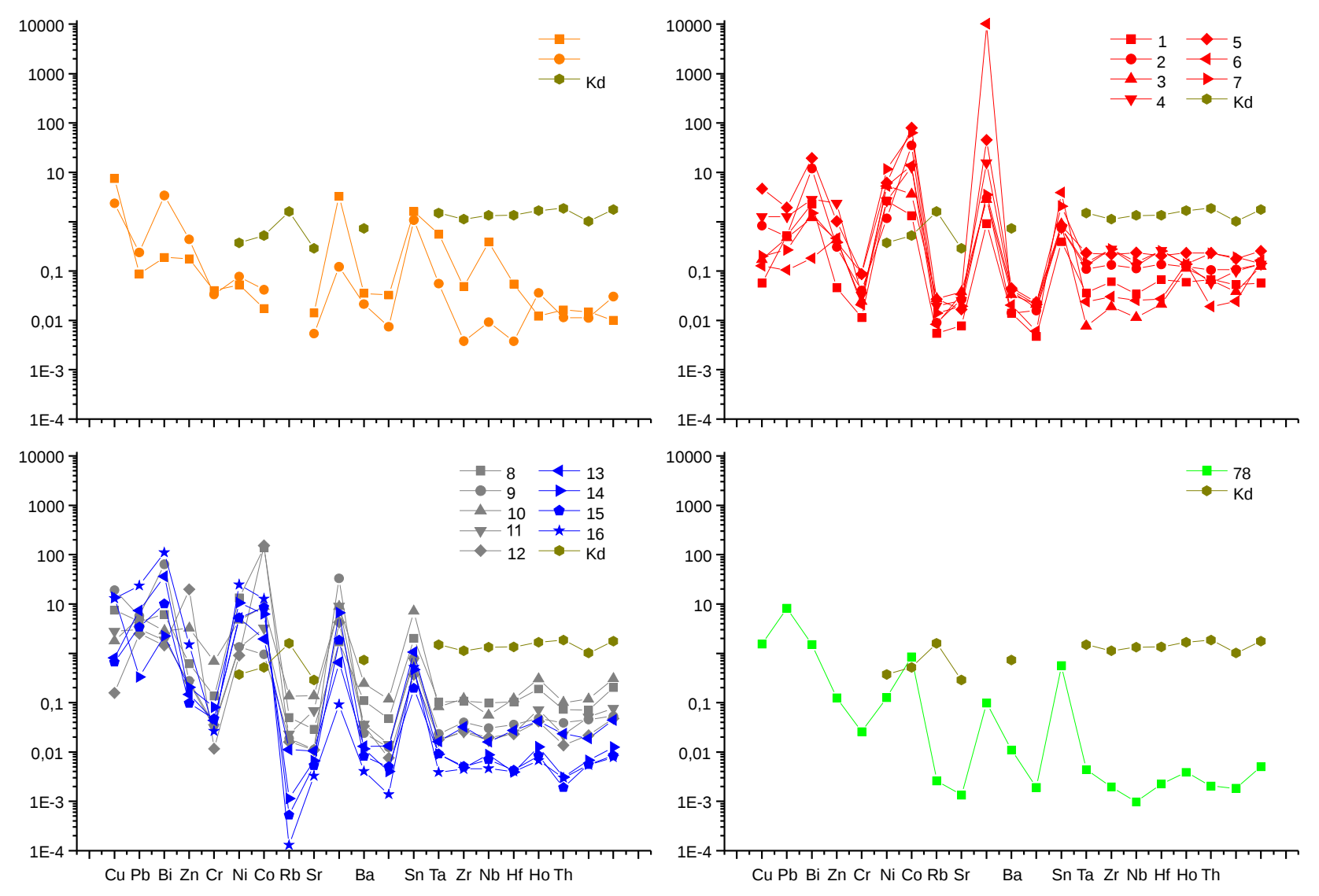



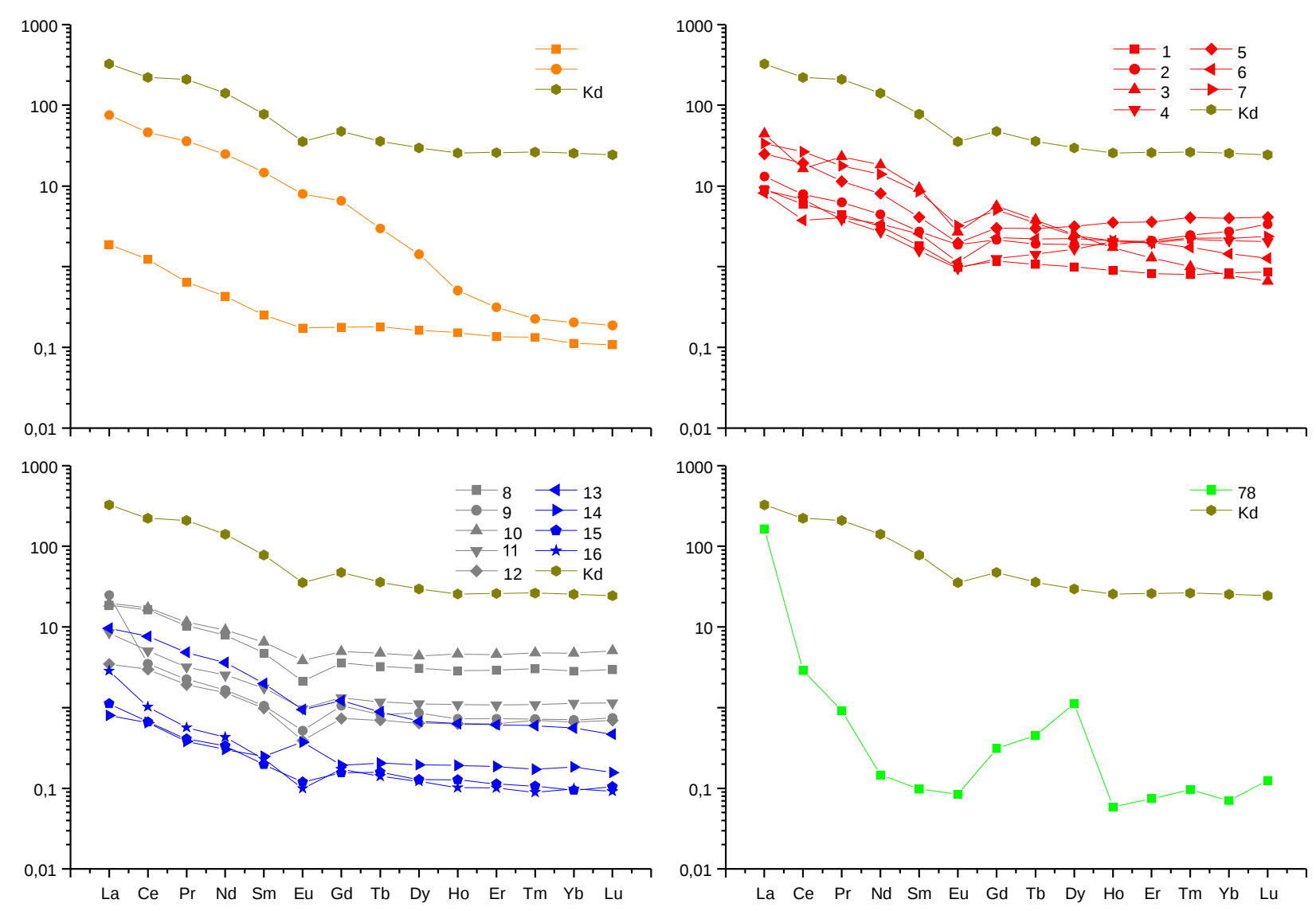

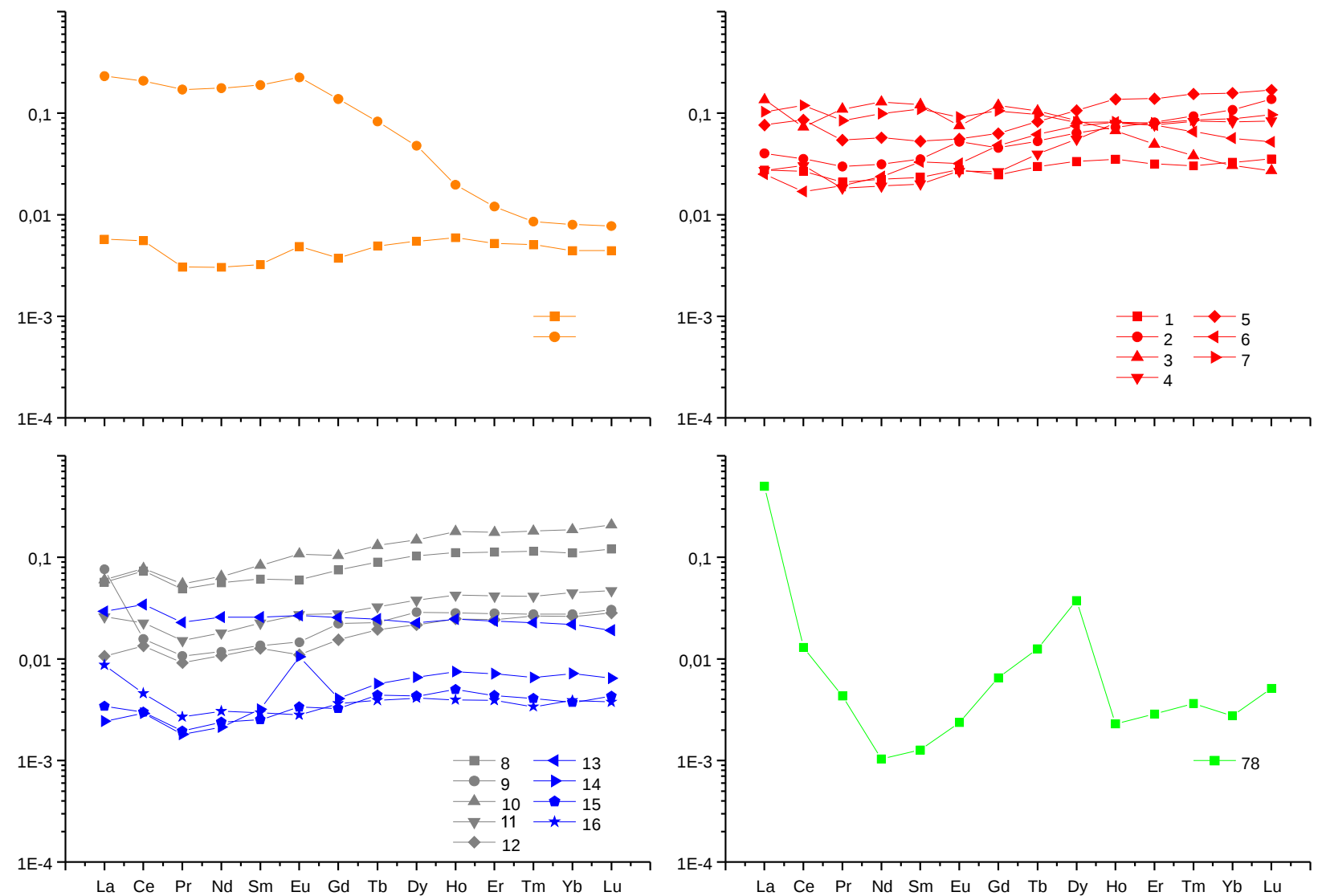

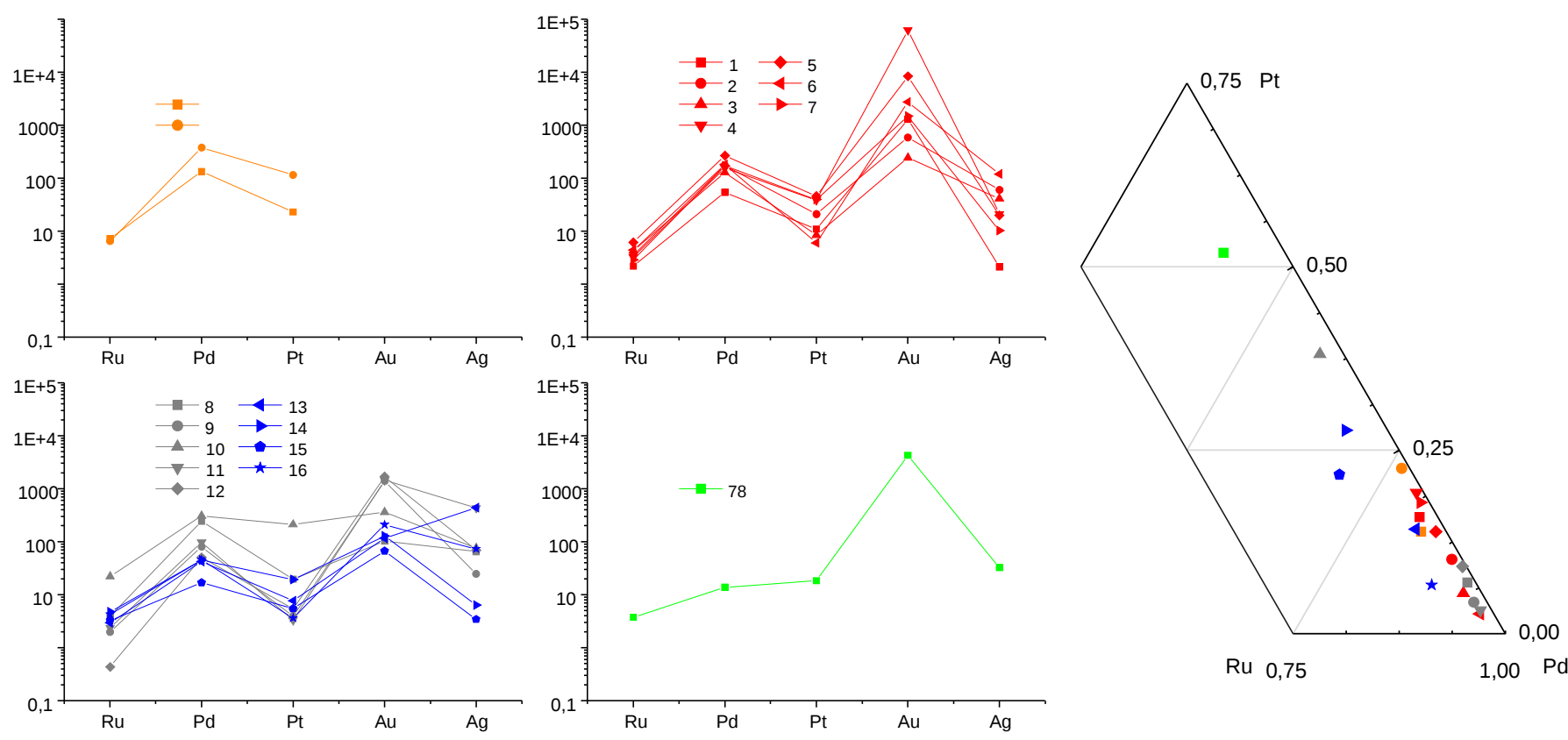